\title{
In situ Sr isotope analyses by LA-MC-ICP- MS of igneous apatite and plagioclase from magmatic rocks at the CPGeo-USP
}

\author{
Microanálises isotópicas de Sr de plagioclásio e \\ apatita magmáticos via LA-MC-ICP-MS no CPGeo-USP
}

Patricio Montecinos Munoz ${ }^{1 *}$, Adriana Alves ${ }^{1}$, Rogério Guitarrari Azzone $^{1}$,
Pablo Cordenons $^{2}$, Sandra Morano ${ }^{3}$, Walter Sproesser ${ }^{1}$, Solange de Souza $^{1}$

ABSTRACT: This contribution describes the successful implementation of in situ $\mathrm{Sr}$ isotope analyses by LA-MC-ICP-MS at the CPGeo-USP. The choice for an analytical configuration using measurements of half-masses allows the accurate assessment of lanthanide interferences, permitting the determination of $\mathrm{Sr}$ isotopes in important REE-rich accessory phases, such as apatite. Likewise, the on-peak-zero method effectively corrects the background contribution (both from $\mathrm{Kr}$ and residual $\mathrm{Sr}$ contributions from previous ablations) to the signals of the unknown samples. The analytical campaigns resulted in an accuracy, in respect to reference TIMS values, better than $57 \mathrm{ppm}(\sim \pm 0.0000572 \sigma$ SD) for a modern coral and the Batjberg clinopyroxene which impart significant quality to our data. Similarly, the majority of the stable $\mathrm{Sr}$ isotope ratios are close to the accepted values, which also confirms the effectiveness of the method. The achieved accuracy allows the identification and investigation of spatially-controlled isotopic heterogeneities on the micrometric scale in several Sr-rich minerals (apatite, carbonates, plagioclase, and clinopyroxene) with important implications to the understanding of relevant geochemical processes, particularly AFC, source geochemical heterogeneities and magma-mixing.

KEYWORDS: Laser ablation; Multiple collector inductively coupled plasma mass spectrometry; Isobaric interferences; Sr isotopic tracing.
RESUMO: A presente contribuição descreve a implementação da rotina de microanálises isotópicas de Sr via LA-MC-ICP-MS no CPGeo-USP. A escolha por uma rotina analitica envolvendo a mediçāo de meias-massas (p.ex. $\left.{ }^{171} Y^{2+}\right)$ possibilitou a adequada correção das interferências de lantanídeos, permitindo a determinação precisa de isotopos de Sr em fases minerais acessórias ricas em $R E E$, como a apatita. O método de mediçōes on-peak-zero permitiu a correção efetiva das contribuiçōes de niveis de branco (Kr + Sr residual na linha de gás) aos sinais de amostras desconhecidas. As razöes ${ }^{87} \mathrm{Sr}{ }^{86} \mathrm{~S}$ r obtidas em diferentes materiais de referência (e.g. coral moderno e o clinopiroxênio Batjberg) alcançaram precisāo menor que 57 ppm ( $\pm 0.0000572 \sigma S D)$ em comparaçäo com os valores certificados via TIMS. A qualidade da rotina implementada é também atestada pela proximidade dos valores aceitos e obtidos para razóes isotópicas estáveis. O grau de exatidão atigindo permite a identificação e o estudo de heterogeneidades isotópicas em escala micrométricas em variados minerais ricos em Sr (apatita, carbonatos, plagioclásio e clinopiroxênio) com importantes implicaçôes para a comprensão de processos geoquímicos relevantes, particulamente processos de assimilaçâa-fraccionamento-contaminação, heterogeneidades químicas e mistura de magmas.

PALAVRAS-CHAVE: Ablaçâo a laser; Spectrometria de massa acoplada a ICP; Interferências isobáricas; Determinaçōes isotópicas de Sr.

\footnotetext{
1Institute of Geosciences, Universidade de São Paulo - USP, São Paulo (SP), Brazil.E-mails: patricio.m.munoz@usp.br, adrianaalves@usp.br, rgazzone@usp.br. wmsproes@usp.br, slsouza@usp.br

${ }^{2}$ Department of Geological Sciences, Universidad de Buenos Aires - UBA, Buenos Aires, Argentina. E-mail: padacorde@gl.fcen.uba.ar ${ }^{3}$ SENS Representações Comerciais, São Paulo (SP), Brazil. E-mail: smorano@sensms.com.br

*Corresponding author.

Manuscript ID: 30293. Received in: 04/29/2015. Approved in: 02/01/2016.
} 


\section{INTRODUCTION}

The in situ analyses of $\mathrm{Sr}$ isotopes have experienced a systematic improvement over the last two decades. The identification, quantification and correction of quality-influence factors allow the acquisition of spatially resolved, accurate data, and the technique has become routine in many isotope geochemistry laboratories worldwide. The versatility of the LA-MC-ICP-MS analyses is reflected on the numerous contributions dedicated to a vast diversity of materials, from magmatic minerals (Davidson et al. 2001, Schmidberger et al. 2003, Ramos et al. 2004) to biogenic carbonate (Adams et al. 2005) and human tooth enamel (Simonetti et al. 2008).

Best accuracy levels obtained via LA-MC-ICP-MS are around tens of $\mathrm{Sr}$ ppm and, therefore under optimal analytical conditions (e.g., high Sr and low Rb contents), resultant Sr isotope data are comparable to those obtained by thermal ionization mass spectrometry (TIMS). Nonetheless, a continuous cast for analytical improvement has aimed the identification of physical factors controlling data quality. Among such factors the (a) isobaric and molecular interferences, (b) instrument mass fractionation, (c) background levels, and (d) counting statistics are the main concerns associated to the acquisition of accurate Sr isotope data (Vroon et al. 2008).

In general, data reduction engages mass bias quantification, correction of the isobaric intereferences and background level effects on Sr isotope masses. Most of the built-in data reduction procedures involve basic interferences correction, and alternative correction schemes are rarely employed.

The present contribution describes the implementation of the in situ LA-MC-ICP-MS Sr isotope analyses at the CPGeo (Centro de Pesquisas Geocronológicas - USP). We present detailed data reduction strategies and petrological applications based on two analytical campaigns dedicated to the determination of $\mathrm{Sr}$ isotopes in widely used standards (e.g., modern coral) and on apatite, plagioclase and carbonate crystals from alkaline rocks, granites and basaltic samples exposed in southeastern Brazil and Central Patagonia, Argentina.

\section{MATERIALS}

It is a consensus that the acquisition of precise in situ ${ }^{87} \mathrm{Sr} /{ }^{86} \mathrm{Sr}$ ratios via LA-MC-ICPMS is mainly controlled by the chemistry of the analyzed material (Vroon et al. 2008) and, due to the isobaric interferences of ${ }^{87} \mathrm{Rb}$ on ${ }^{87} \mathrm{Sr}$, best results are achieved in $\mathrm{Sr}$-rich and $\mathrm{Rb}$-poor phases $(\mathrm{Rb} / \mathrm{Sr}<0.02)$.

In Earth's most abundant rocks, apatite, clinopyroxene, carbonates and plagioclase usually meet the chemical criteria (low $\mathrm{Rb} / \mathrm{Sr}$ ), which, combined with the fact that these minerals saturate early during the evolution of acid (apatite and plagioclase), basic (clinopyroxene, plagioclase and apatite) and alkaline (apatite and carbonate) magmas, allows unravel of protracted igneous histories in different geological scenarios (e.g., Davidson et al. 2001, Alves et al. 2009).

Mineral isotopic disequilibrium and heterogeneity appear to be the rule rather than the exception (Farina et al. 2014). An unfortunate consequence of such rare isotope homogeneity on the mineral scale is the scarcity of matrix-matching natural standards, especially for plagioclase.

In this contribution, we adopt the same strategy of several reference studies dedicated to in situ $\mathrm{Sr}$ isotopes in different minerals and use a REE- and Rb- poor present-day marine carbonate (Sr: 1000 - 2000 ppm) as an "in-house" standard to check for external reproducibility (Bizarro et al. 2003, Schmidberger et al. 2003, Ramos et al. 2004). Additional examples include the use of in-house apatite, clinopyroxene and plagioclase crystals as reference materials in non matrixmatched Sr isotope determinations on epidote, carbonates, plagioclase and basaltic glasses (Chen et al. 2015, Guo et al. 2014). To reduce $\mathrm{Rb}$ corrections to a minimum, only analyses that yielded $\mathrm{Rb} / \mathrm{Sr}$ ratios lower than 0.02 and ${ }^{88} \mathrm{Sr}$ signal $>1 \mathrm{~V}$ are considered. Therefore, there was no need to include matrix-matched standards and age corrections resulted negligible differences if compared with measured ${ }^{86} \mathrm{Sr} /{ }^{87} \mathrm{Sr}$ (low $\mathrm{Rb} / \mathrm{Sr}$ and radiometric ages ranging from -25 to $580 \mathrm{Ma}$ ).

The acquisition of accurate $\mathrm{Sr}$ isotope data in Fe-bearing minerals was investigate via analyses of ther the Batjberg clinopyroxene, collected from alkaline basaltic lavas from the Batjberg ultrapotassic complex in Greenland. The clinopyroxene from basaltic rocks usually have low $\mathrm{Rb}$ and HREE contentes ( $\mathrm{Rb} / \mathrm{Sr}$ ratios from $3 \times 10^{-6}$ to 0.16 and $\mathrm{Yb}$ from 0.05 to $6.6 \mathrm{ppm}$, data from Georoc database), which strongly support a very limited interference of $\mathrm{Rb}$ and $\mathrm{Yb}$ on $\mathrm{Sr}$ isotopes.

In order to present a broad scenario of possible applications, we measured Sr isotope ratios of the following materials: - Plagioclase crystals from granites (Salto pluton, Brazil; Alves et al. 2015), mafic and ultramafic cumulates (Ponte Nova massif, Brazil, PN; Azzone et al. 2009), and trachytes from Somún Curá Plateau (SCP, Argentina; Cordenons et al. 2014).

- Apatite crystals from trachytes (SCP) and cumulates (PN).

- Calcite and dolomite crystals from carbonatites from Jacupiranga Complex.

The chosen materials allow tracking of the contribution from different sources (enriched mantle, depleted mantle, and crust) and processes (equilibrium fractional crystallization, AFC and magma mixing), and, therefore, selected applications are intented to give an idea about the problems that can be addressed using the described technique. 


\section{ANALYTICAL PROCEDURES}

\section{Mass spectrometry configuration and ablation conditions}

Analytical procedures were developed using a $193 \mathrm{~nm}$ Ar-F excimer laser coupled to a ThermoFinnigan Neptune ${ }^{T M}$ Mass Spectrometer equipped with 9 Faraday collectors (with $10^{-11} \Omega$ resistors) with operating conditions, which are summarized in Table1. Two analytical campaigns separated in time were executed in order to allow the investigation of time-dependent fluctuations (June 2014 and January 2015).

Cup configuration followed Ramos et al. (2004) and successfully accounted for isobaric interferences on $\mathrm{Sr}$ isotope masses (Table 1). Collector alignment was performed using pure REE solutions $(100 \mu \mathrm{g} / \mathrm{g}$ of Er and $100 \mu \mathrm{g} / \mathrm{g}$ of $\mathrm{Yb}$, both dissolved in $3 \% \mathrm{HNO}_{3}$ ) and a $200 \mathrm{ppb}$ solution of $\mathrm{Sr}$ dissolved in $3 \% \mathrm{HNO}_{3}$. The amplifier gain calibration was performed daily, and all isotope data were acquired in static, multi-collection mode. The amplifiers were sequentially connected to all the Faraday collectors in order to minimize potential gain calibration errors.

Prior to each analysis, data acquisition consisted of a 60 second background level measurement (as in a normal analysis, but without firing the laser), and baselines were measured on-peak. We used these gas blank levels to subtract background effects from unknown samples.

For each analytical day, 8 to 9 Sr measurements were obtained in a modern coral standard (Bizzarro et al. 2003, Schmidberger et al. 2003) to monitor the instrumental fractionation of $\mathrm{Sr}$ masses and to determine the external reproducibility of the method. The external reproducibility of the method on Fe-bearing phases, in which $\mathrm{FeO}$ is a possible interferant on $\mathrm{Sr}$, was investigated via analyses of the Batberjg clinopyroxene (Adams et al. 2005). The spot dimensions varied from 80 to $160 \mu \mathrm{m}$ as a function of the characteristics of the mineral phase being ablated, pulse rate ranged between 6 and $10 \mathrm{~Hz}$, and the used pulse energy (between 6 and $8.5 \mathrm{~mJ}$ ) resulted energy density from 4 to $12 \mathrm{~J} / \mathrm{cm}^{2}$.

\section{Interferences}

The accuracy of resultant ${ }^{87} \mathrm{Sr} /{ }^{86} \mathrm{Sr}$ ratios is directly related to the ability to successfully account and correct for isobaric interferences (Table 1). In the following section, we summarize in order of importance such interferences and present the procedures adopted for correction (Table 2).

\section{$\mathbf{R b}$ isobaric interferences}

The ${ }^{87} \mathrm{Rb}$ interference over ${ }^{87} \mathrm{Sr}$ (Table 1a) is the main factor controlling the feasibility in situ $\mathrm{Sr}$ isotopic analyses. As a rule of thumb, materials with $\mathrm{Rb} / \mathrm{Sr}$ ratios $>0.02$ are not suitable for the acquisition of accurate $\mathrm{Sr}$ isotope ratios via LA-MC-ICP-MS (Ramos et al. 2004), whereas others advocate that an efficient correction can be performed for materials with far greater $\mathrm{Rb} / \mathrm{Sr}$ ratios $(<0.2$ Davidson et al. 2001). The isobaric ${ }^{87} \mathrm{Rb}$ contribution over ${ }^{87} \mathrm{Sr}$ was corrected by using the ${ }^{85} \mathrm{Rb}$ ion signal and the ${ }^{87} \mathrm{Rb} /{ }^{85} \mathrm{Rb}$ natural ratio (e.g., Ramos et al. 2004). This correction considers that the $\mathrm{Rb}$ mass bias factor ( $(\mathrm{Rb})$ is similar to the $\mathrm{Sr}$ mass bias $(\mathrm{BSr})$.

\section{Background}

Krypton is present as an impurity in argon, the carrier gas used in the LA-MC-ICP-MS analyses (e.g., Paton et al. 2007); it interferes on ${ }^{84} \mathrm{Sr}$ and ${ }^{86} \mathrm{Sr}$ masses (Table 1a). Total $\mathrm{Kr}$ signal might range between $0.5 \mathrm{mV}$ and $50 \mathrm{mV}$ (Ramos et al. 2004, Paton et al. 2007, Yang et al. 2011). The commonly used correction for this background contribution is based on "on-peak-zero" measurements (OPZ) and subsequent subtraction of the blank analyses from the unknown signals (Davidson et al. 2001, Bizzarro et al. 2003, Schmidberger et al. 2003, Ramos et al. 2004, Paton et al. 2007). An alternative procedure is based on the ${ }^{83} \mathrm{Kr}$ "peak stripping method", but potential interferences on the mass 83 cannot be easily assessed (e.g., $\mathrm{ZnO}$ and $\mathrm{CaAr}^{+}$) (Christensen et al. 1995, Waight et al. 2002, Jackson \& Hart 2006, Vroon et al. 2008).

All of our reduction strategies were performed via OPZ measurement, but in two procedures an extra step including the evaluation of $\mathrm{Kr}$ mass bias $(\mathrm{BKr})$ and ${ }^{83} \mathrm{Kr}$ peak stripping method was included subsequently to correct for any remaining Kr interference (e.g., Waight et al. 2002) (Table 2). The $B \mathrm{Kr}$ was calculated by comparison between the measured ${ }^{83} \mathrm{Kr} /{ }^{84} \mathrm{Kr}$ and the natural ${ }^{83} \mathrm{Kr} /{ }^{84} \mathrm{Kr}$ ratios $(-0.203)$.

\section{$\mathrm{REE}^{2+}$}

The doubly charged lanthanide ions $\left(\mathrm{REE}^{2+}\right)$ can interfere on Sr isotope masses (Table 1a, e.g., Waight et al. 2002, Ramos et al. 2004). The magnitude of the $\mathrm{Yb}^{2+}$ interference over $\mathrm{Sr}$ isotopes is a function of the total $\mathrm{Yb}$ content of the analyzed material because this doubly charged species interferes in decreasing order of severity on masses 87,86 and 84. For instance, Ramos et al. (2004) reported increasing ${ }^{87} \mathrm{Sr} /{ }^{86} \mathrm{Sr}$ ratios concurrent with increased $\mathrm{Yb}$ contents, with an anthitetic behavior observed for ${ }^{84} \mathrm{Sr} /{ }^{86} \mathrm{Sr}$ ratios. Similarly, ${ }^{168} \mathrm{Er}^{2+}$ interferences on ${ }^{84} \mathrm{Sr}$ isotope might result in higher ${ }^{84} \mathrm{Sr} /{ }^{86} \mathrm{Sr}$ ratio.

In addition, interactions between $\mathrm{REE}^{2+}$ and the carrier gas in REE-rich substrates might produce Gd oxide and nitride molecules that potentially interfere over all Sr masses and over ${ }^{171 / 173} \mathrm{Yb}^{2+}$. This phenomenon cannot be accounted for in the analytical protocol employed, but it should be minor in phases carrying high $\mathrm{Sr}$ and very low Gd contents. 
Table 1. Interferences on $\mathrm{Sr}$ isotope masses and instrument configuration.

\begin{tabular}{|c|c|c|c|c|c|c|c|c|c|}
\hline Mass & 83 & 84 & 85 & 85.5 & 86 & 86.5 & 87 & 88 & \\
\hline Analyte & ${ }^{166} \mathrm{Er}^{+2}$ & ${ }^{84} \mathrm{Sr}$ & ${ }^{85} \mathrm{Rb}$ & ${ }^{171} \mathrm{Yb}^{+2}$ & ${ }^{86} \mathrm{Sr}$ & ${ }^{173} \mathrm{Yb}^{+2}$ & ${ }^{87} \mathrm{Sr}$ & ${ }^{88} \mathrm{Sr}$ & \\
\hline \multicolumn{10}{|c|}{ Isobaric interferences } \\
\hline & ${ }^{168} \mathrm{Er}^{+2}$ & ${ }^{168} \mathrm{Er}^{+2}$ & ${ }^{170} \mathrm{Er}^{+2}$ & & & & & & \\
\hline & ${ }^{83} \mathrm{Kr}$ & ${ }^{84} \mathrm{Kr}$ & & & ${ }^{86} \mathrm{Kr}$ & & & & \\
\hline & & ${ }^{168} \mathrm{Yb}^{+2}$ & ${ }^{170} \mathrm{Yb}^{+2}$ & & ${ }^{172} \mathrm{Yb}^{+2}$ & & ${ }^{174} \mathrm{Yb}^{+2}$ & ${ }^{176} \mathrm{Yb}^{+2}$ & \\
\hline & & & & & & & ${ }^{174} \mathrm{Hf}^{+2}$ & ${ }^{176} \mathrm{Hf}^{+2}$ & \\
\hline & & & & & & & ${ }^{87} \mathrm{Rb}$ & & \\
\hline \multicolumn{10}{|c|}{ Potential molecular interferences } \\
\hline Gd - Nitrides & ${ }^{152} \mathrm{Gd}^{14} \mathrm{~N}$ & ${ }^{154} \mathrm{Gd}^{14} \mathrm{~N}$ & ${ }^{156} \mathrm{Gd}^{14} \mathrm{~N}$ & ${ }^{157} \mathrm{Gd}^{14} \mathrm{~N}$ & ${ }^{158} \mathrm{Gd}^{14} \mathrm{~N}$ & & ${ }^{160} \mathrm{Gd}^{14} \mathrm{~N}$ & & \\
\hline Gd - Oxides & & ${ }^{152} \mathrm{Gd}^{16} \mathrm{O}$ & ${ }^{154} \mathrm{Gd}^{16} \mathrm{O}$ & ${ }^{155} \mathrm{Gd}^{16} \mathrm{O}$ & ${ }^{156} \mathrm{Gd}^{16} \mathrm{O}$ & ${ }^{157} \mathrm{Gd}^{16} \mathrm{O}$ & ${ }^{158} \mathrm{Gd}^{16} \mathrm{O}$ & ${ }^{160} \mathrm{Gd}^{16} \mathrm{O}$ & \\
\hline \multirow[t]{3}{*}{ Ca dimers } & ${ }^{40} \mathrm{Ca}^{43} \mathrm{Ca}$ & ${ }^{40} \mathrm{Ca}^{44} \mathrm{Ca}$ & ${ }^{42} \mathrm{Ca}^{43} \mathrm{Ca}$ & & ${ }^{40} \mathrm{Ca}^{46} \mathrm{Ca}$ & & & ${ }^{40} \mathrm{Ca}^{48} \mathrm{Ca}$ & \\
\hline & & & & & ${ }^{42} \mathrm{Ca}^{44} \mathrm{Ca}$ & & & ${ }^{42} \mathrm{Ca}^{46} \mathrm{Ca}$ & \\
\hline & & & & & ${ }^{43} \mathrm{Ca}_{2}$ & & ${ }^{43} \mathrm{Ca}^{44} \mathrm{Ca}$ & ${ }^{44} \mathrm{Ca}_{2}$ & \\
\hline \multirow[t]{3}{*}{ Ca argides } & ${ }^{43} \mathrm{Ca}^{40} \mathrm{Ar}$ & ${ }^{48} \mathrm{Ca}^{36} \mathrm{Ar}$ & & & ${ }^{48} \mathrm{Ca}^{38} \mathrm{Ar}$ & & & & \\
\hline & & ${ }^{46} \mathrm{Ca}^{38} \mathrm{Ar}$ & & & & & & & \\
\hline & & ${ }^{44} \mathrm{Ca}^{40} \mathrm{Ar}$ & & & ${ }^{46} \mathrm{Ca}^{40} \mathrm{Ar}$ & & ${ }^{40} \mathrm{Ca}^{31} \mathrm{P}^{16} \mathrm{O}$ & ${ }^{48} \mathrm{Ca}^{40} \mathrm{Ar}$ & \\
\hline \multirow[t]{3}{*}{ Fe oxides } & & & & & ${ }^{54} \mathrm{Fe}^{16} \mathrm{O}_{2}$ & & ${ }^{54} \mathrm{Fe}^{16} \mathrm{O}^{17} \mathrm{O}$ & ${ }^{54} \mathrm{Fe}^{16} \mathrm{O}^{18} \mathrm{O}$ & \\
\hline & & & & & & & & ${ }^{54} \mathrm{Fe}^{17} \mathrm{O}_{2}$ & \\
\hline & & & & & & & & ${ }^{56} \mathrm{Fe}^{16} \mathrm{O}_{2}$ & \\
\hline \multicolumn{10}{|c|}{ Table 1b: Cup configuration and instrument operating parameters } \\
\hline \multicolumn{10}{|l|}{ Cup configuration } \\
\hline Collector & L4 & L3 & L2 & L1 & Axial & $\mathrm{H} 1$ & $\mathrm{H} 2$ & $\mathrm{H} 3$ & $\mathrm{H} 4$ \\
\hline MASS & & 83 & 84 & 85 & 85.5 & 86 & 86.5 & 87 & 88 \\
\hline Analyte & & ${ }^{166} \mathrm{Er}^{+2}$ & ${ }^{84} \mathrm{Sr}$ & ${ }^{85} \mathrm{Rb}$ & ${ }^{171} \mathrm{Yb}^{+2}$ & ${ }^{86} \mathrm{Sr}$ & ${ }^{173} \mathrm{Yb}^{+2}$ & ${ }^{87} \mathrm{Sr}$ & ${ }^{88} \mathrm{Sr}$ \\
\hline \multicolumn{10}{|c|}{ Instrument operating parameters } \\
\hline $\mathrm{MC}-\mathrm{ICP}-\mathrm{MS}$ & & & & & & \multicolumn{4}{|c|}{ Laser ablation system } \\
\hline $\begin{array}{l}\text { Brand and } \\
\text { model }\end{array}$ & & \multicolumn{3}{|c|}{ Thermo Finnigan Neptune } & & \multicolumn{2}{|c|}{ Type } & \multicolumn{2}{|c|}{$\begin{array}{c}193 \mathrm{~nm} \text { Ar - F excimer } \\
\text { laser }\end{array}$} \\
\hline Forward power & & $1250 \mathrm{~W}$ & & & & \multicolumn{2}{|c|}{ Model } & \multicolumn{2}{|c|}{ Analyte G2 } \\
\hline \multirow[t]{2}{*}{ Mass resolution } & & Low (400) & & & & \multicolumn{2}{|c|}{ Repetition rate } & \multicolumn{2}{|c|}{$6-10 \mathrm{~Hz}$} \\
\hline & & & & & & \multicolumn{2}{|c|}{ Pulse energy } & \multicolumn{2}{|c|}{$6-8.5 \mathrm{~mJ}$} \\
\hline Gas flows & & & & & & \multicolumn{2}{|c|}{ Spot size } & \multicolumn{2}{|c|}{$80-160 \mu \mathrm{m}$} \\
\hline Cool plasma (Ar) & & \multicolumn{2}{|c|}{$15.5 \mathrm{~L} / \mathrm{min}$} & & & \multicolumn{2}{|c|}{ Laser fluence } & \multicolumn{2}{|c|}{$4-12 \mathrm{~J} / \mathrm{cm}^{2}$} \\
\hline Auxiliary (Ar) & & \multicolumn{2}{|c|}{$1.0 \mathrm{~L} / \mathrm{min}$} & & & & & & \\
\hline $\begin{array}{l}\text { Sample carrier } \\
\text { gas }(\mathrm{He})\end{array}$ & & \multicolumn{2}{|c|}{$1.0 \mathrm{~L} / \mathrm{min}$} & & & & & & \\
\hline
\end{tabular}




\section{Potential molecular interferences $(\mathrm{Ca}$ and $\mathrm{Fe})$}

The interference of calcium molecular species (Ramos et al. 2004, Yang et al. 2011) and Fe oxides (e.g., masses $86\left[\sim^{54} \mathrm{Fe}^{32} \mathrm{O}\right]$ and $88\left[{ }^{56} \mathrm{Fe}^{32} \mathrm{O}\right]$, Schmidberger et al. 2003) have been demonstrated to be of limited effect on LA-MC-ICP-MS Sr isotope analyses (Table 1a). Since the used configuration does not allow measurement of an interference-free Fe mass, the reduction protocols presented cannot correct for such contributions. However, ${ }^{87} \mathrm{Sr} /{ }^{86} \mathrm{Sr}$ ratios obtained on the Batjberg clinopyroxene are close to the TIMS values, further evidencing the limited interference of $\mathrm{FeO}$ over $\mathrm{Sr}$ isotope masses (see Table 3).

\section{Instrumental mass discrimination on $\mathrm{Sr}$ and $\mathrm{Yb}$ masses}

One of the main obstacles for the acquisition of accurate ${ }^{87} \mathrm{Sr} /{ }^{86} \mathrm{Sr}$ is the difficulty of accurately establishing the Sr instrumental mass bias ( $\mathrm{BS}$ r factor). Fractionation during analysis, has been extensively documented in various studies, both in laser ablation and solution mode (Halliday et al. 1995, Christensen et al. 1995, Albarède $\&$ Beard 2004) and the phenomen can be corrected using the ${ }^{86} \mathrm{Sr} /{ }^{88} \mathrm{Sr}$ measured during the analyses and the natural ${ }^{86} \mathrm{Sr} /{ }^{88} \mathrm{Sr}$ ratio $(=0.1194)$, and assuming an exponential relantioship between the two and one unit mass differences.

The instrumental fractionation on $\mathrm{Yb}$ masses ( $\mathrm{Y} \mathrm{Yb}$ factor) was assessed by comparing the measured ${ }^{171} \mathrm{Yb}^{+2} /{ }^{173} \mathrm{Yb}^{+2}$ (masses 85.5 and 86.5 ) ratio with the natural ${ }^{171} \mathrm{Yb}^{+2} /{ }^{173} \mathrm{Yb}^{+2}$ ratio (Table 2). Note that molecular GdO interferes on most $\mathrm{Yb}$ and an advantage of measuring the half masses is the likelihood of $\mathrm{GdO}^{+2}$ is very small, removing the concern about $\mathrm{GdO}$ interference on $\mathrm{Yb}$.

\section{Data reduction strategies}

Previous LA-MC-ICP-MS studies have strongly favoured the application of a cascade of corrections for interferences and mass bias fractionations (McFarlane \& McCulloch 2008, Vroon et al. 2008). Our raw data and background signals were reduced in an offline excel spreadsheet, modified from Chen \& Simonetti (2013). The correction scheme was, in order:

subtraction of background contributions;

- subtraction of $\mathrm{Yb}^{2+}$ interference;

- subtraction of $\mathrm{Er}^{2+}$ interference;

- subtraction of ${ }^{87} \mathrm{Rb}$ interference;

- Sr mass bias correction ( $\mathrm{BSr}$ ); and

- $2 \sigma$ outlier test.

We tested different combinations of the above procedures (corrections Type 0 to Type 5) on the reference materials datasets resulted from the June 2014 campaign (Table 2). The quality of the respective outcomes indicates that correction Type 1 is the most effective procedure, and consequently this protocol was used to correct $\mathrm{Sr}$ isotope ratios of the unknowns (see results section).

\section{Measurement of precision and accuracy}

A description of the assessment of precision and accuracy is given here in order to clarify the approach used. On unknown samples and referential material the average Sr isotope value were calculated using the mathematical expression for the arithmetic mean.

The internal precision was calculated for each analysis (considering all 60 cycles per spot) using:

Table 2. Outline of data reduction types used in this study.

\begin{tabular}{|c|c|c|c|c|c|c|c|c|c|c|}
\hline \multicolumn{11}{|c|}{ ( $\checkmark$ indicate applied correction) } \\
\hline \multirow[b]{2}{*}{$\begin{array}{l}\text { Reduction } \\
\text { Type }\end{array}$} & \multicolumn{4}{|c|}{ On background levels } & \multicolumn{6}{|c|}{ On net signals (after background corrections) } \\
\hline & OPZ & $\begin{array}{c}\mathrm{Kr} \\
\text { mass } \\
\text { bias }\end{array}$ & $\begin{array}{c}{ }^{86} \mathrm{Kr} \text { : calculated } \\
\text { from }{ }^{83} \mathrm{Kr} \text { peak } \\
\text { stripping }\end{array}$ & $\begin{array}{l}{ }^{86} \mathrm{Sr} \text { : calculated } \\
\text { from }{ }^{88} \mathrm{Sr} \text { peak } \\
\text { stripping }\end{array}$ & $\begin{array}{c}\mathrm{REE}^{+2} \\
\text { substraction }\end{array}$ & $\begin{array}{c}\text { Yb } \\
\text { mass } \\
\text { bias }\end{array}$ & $\begin{array}{c}\text { Er } \\
\text { mass } \\
\text { bias }\end{array}$ & $\begin{array}{c}{ }^{87} \mathrm{Rb} \\
\text { substraction }\end{array}$ & $\begin{array}{c}\text { Sr mass } \\
\text { bias }\end{array}$ & $\begin{array}{l}2 \sigma \text { test } \\
\text { outlier }\end{array}$ \\
\hline Type 0 & $\checkmark$ & & & & & & & $\checkmark$ & $\checkmark$ & $\checkmark$ \\
\hline Type 1 & $\checkmark$ & & & & $\checkmark$ & & & $\checkmark$ & $\checkmark$ & $\checkmark$ \\
\hline Type 2 & $\checkmark$ & & & & $\checkmark$ & $\checkmark$ & & $\checkmark$ & $\checkmark$ & $\checkmark$ \\
\hline Type 3 & $\checkmark$ & $\checkmark$ & $\checkmark$ & & $\checkmark$ & $\checkmark$ & $\checkmark$ & $\checkmark$ & $\checkmark$ & $\checkmark$ \\
\hline Type 4 & $\checkmark\left({ }^{*}\right)$ & $\checkmark$ & $\checkmark$ & $\checkmark$ & $\checkmark$ & $\checkmark$ & $\checkmark$ & $\checkmark$ & $\checkmark$ & $\checkmark$ \\
\hline Type 5 & $\checkmark\left({ }^{*}\right)$ & & $\checkmark$ & $\checkmark$ & $\checkmark$ & & & $\checkmark$ & $\checkmark$ & $\checkmark$ \\
\hline
\end{tabular}

Notes: (*) On-peak zeroes (OPZ) method was applied on all background intensities with exception of mass 86 .

- All reductions were tested only on June 2014 referential materials.

- Reduction type 1 was applied to unknowns of the second analytical campaign (Table 4). 
$\pm 2 \sigma S D=\frac{t_{97.5,58}{ }^{*} S D_{\text {ind }}}{\sqrt{N C}}$

where $S D_{\text {ind }}$ is individual standard deviation, $\mathrm{NC}$ is the number of cycles (60), and $t_{97.5,58}$ is the two-sided Student's $t$ value for $\mathrm{n}-2$ degrees of freedom (58), which corresponds to a value of 2.002 (Spiegel 1975).

The external reproducibility (external precision), $2 \sigma$ $\mathrm{SD}$, corresponds to the precision of replicate measurements. In the case of referential materials, it corresponds to precision of determinations obtained in different regions of the same grain (Table 3), whereas for unknown samples it represents the overall precision for analyses in different grains (Table 4). The following mathematical expression was used (Allègre 2005):

$\pm 2 \sigma S D=t_{97.5, n-1} * \frac{1}{\sqrt{\frac{1}{n} \sum \frac{1}{\sigma_{X_{i}}^{2}}}} * \sqrt{\frac{\left[\left(X_{i}-\bar{X}\right)^{2} / \sigma_{X_{i}}^{2}\right]}{n-1}}$

where $n$ is the number of determinations, $t_{97.5, n-1}$ is the twosided Student's $t$ value for $n-1$ degrees of freedom (with values taken from Spiegel 1975), $\sigma_{X i}^{2}$ is the internal precision (calculated using Eq. 1), $X_{i}$ is the value of each individual determination, $\bar{X}$ is the average of all values measured in a given sample, and the unweighted MSWD (Mean Square Weighted Determination) was calculated using the third factor of Eq. 2, which permits inclusion of data scattering on the calculation of standard deviation. Calculations for average and standard deviation values were independently verified using ISOPLOT-3.0 (Luwdig 2003).

The accuracy was reported as the absolute difference between the average value for ${ }^{87} \mathrm{Sr} /{ }^{86} \mathrm{Sr}$ ratio determined using LA-MC-ICP-MS and the isotope ratio obtained using TIMS $\left(\Delta^{87} \mathrm{Sr} /{ }^{86} \mathrm{Sr} \times 10^{6}\right.$, Table 3$)$.

\section{RESULTS}

\section{Background signals}

Figure 1 shows the variation in gas background signal intensities of both analytical campaigns. Mass 83 intensities ranged, on average, from 0.0003 to $0.0005 \mathrm{~V}$ for the first campaign and from 0.0007 to $0.001 \mathrm{~V}$ for the January 2015 campaign. Signals of masses 86 and 88 ranged from 0.008 to $0.002 \mathrm{~V}$, and 0.001 to $0.009 \mathrm{~V}$, respectively. The average
${ }^{85} \mathrm{Rb}$ background signals varied between $10^{-5}$ and $10^{-4} \mathrm{~V}$, and average $\mathrm{Kr}$ signals were $0.05 \mathrm{~V}$, whereas background $\mathrm{Yb}^{2+}$ intensities were mostly negligible (negative values).

Background signals result from a mixed contribution of the $\mathrm{Ar}(+\mathrm{Kr})$ gas and the $\mathrm{Sr}$ derived from previous analyses. This is evident from the steady behavior of the 83 , 86 and 88 masses during the first 20 analyses dedicated to coral measurements (Fig. 1) and from the irregular increase in the 88 and 86 masses afterwards (when different phases were ablated). Signal fluctuation observed on these signals (86 and 88 masses) is probably an effect of the cumulative residual $\mathrm{Sr}$ signals from previous ablations.

\section{Net signals: $\mathrm{REE}^{+2}, \mathrm{Rb}$ and $\mathrm{Sr}$ intensities in reference materials and unknowns}

Average ${ }^{171,173} \mathrm{Yb}^{+2}$ and ${ }^{166} \mathrm{Er}^{+2}$ net signals (i.e., gas background corrected) varied between 0.01 and $0.05 \mathrm{mV}$, and from 0.02 to $0.20 \mathrm{mV}$, respectively. The maximum $\mathrm{REE}^{+2}$ intensities are 25 times lower than average total $\mathrm{Kr}$ signal in the background. Average signals of ${ }^{173} \mathrm{Yb}^{+2}$ and ${ }^{171} \mathrm{Yb}^{+2}$ masses of the complete dataset (standards and unknowns) did not correlate and resulted in large variation of the $\mathrm{BYb}$ factor from -22 to +80 (not shown).

Data on carbonate and apatite yielded average ${ }^{85} \mathrm{Rb}$ net signal raging from 0.02 to $0.24 \mathrm{mV}$ (with the exception of two analyses on Chacays trachyte apatite which have 1.3 and $2.3 \mathrm{mV}$ of ${ }^{85} \mathrm{Rb}$ net signal). The Batjberg clinopyroxene resulted in average ${ }^{85} \mathrm{Rb}$ net signal varying from 0.03 to $0.50 \mathrm{mV}$, with average total $\mathrm{Rb}$ signal of $3.2 \mathrm{mV}$. The exception to this low ${ }^{85} \mathrm{Rb}$ scenario was observed for plagioclase crystals, which show a broad variation in $\mathrm{Rb} / \mathrm{Sr}$ ratios that implied average ${ }^{85} \mathrm{Rb}$ net signal between 0.02 and $4.60 \mathrm{mV}$, which are discussed in the case studies section.

Average ${ }^{88} \mathrm{Sr}$ and ${ }^{86} \mathrm{Sr}$ net signals define a well-correlated trend (Fig. 2a) with a slope value of $0.115 \pm 0.011(1 \sigma \mathrm{SD})$. This corresponds to a mean $ß S r$ value of $-1.48 \pm 0.24$ ( $1 \sigma \mathrm{SD})$.

\section{In situ $\mathrm{Sr}$ isotope analysis of reference materials: data quality and variation}

The value of the measured ${ }^{87} \mathrm{Sr} /{ }^{86} \mathrm{Sr}$ in the modern coral sample, a Sr-rich and Rb and REE-poor material, is taken to be that of present-day seawater (Hodell et al. 1990), and accuracy of our data reduction schemes are judged against this. For the Batjberg clinopyroxene, a Fe-bearing moderate Sr-rich and moderate REE-bearing mineral, we considered the average TIMS ${ }^{87} \mathrm{Sr} /{ }^{86} \mathrm{Sr}$ ratio value of $0.704474 \pm 17(2 \sigma$ SD; Adams et al. 2005). For each data reduction scheme (Table 2), the accuracy is expressed as the absolute deviation regarding referential values $\left(\Delta^{87} \mathrm{Sr} /{ }^{86} \mathrm{Sr} \times 10^{6} \mathrm{ppm}\right.$, Table 3$)$.

For the ${ }^{87} \mathrm{Sr} /{ }^{86} \mathrm{Sr}$ determinations, both $2 \sigma$ external reproducibility and average $2 \sigma$ internal precisions increased with 
the complexity of the reduction protocol applied (Table 2, see Section 3.5). In contrast, accuracy of the ${ }^{87} \mathrm{Sr} /{ }^{86} \mathrm{Sr}$ ratio was better when simple reduction strategies were applied (Type 1 and 5). The use of more complex protocols yielded external reproducibility twice as high than those obtained using type 1 and 5 reduction schemes (Table 3 ). In all the performed correction schemes, average ${ }^{87} \mathrm{Sr} /{ }^{86} \mathrm{Sr}$ values are very close to the literature ratios determined by TIMS. For instance, correction types 1 and 5 yielded ${ }^{87} \mathrm{Sr} /{ }^{86} \mathrm{Sr}$ ratios only $30 \mathrm{ppm}$ divergent from the accepted modern coral value (showed in bold in Table 3).

The application of different reduction protocols did not have a significant effect upon the ${ }^{84} \mathrm{Sr} /{ }^{88} \mathrm{Sr}$ and ${ }^{84} \mathrm{Sr} /{ }^{86} \mathrm{Sr}$ invariant ratios, as these averaged values almost identical to the accepted values, regardless of the reduction scheme, ${ }^{84} \mathrm{Sr} /{ }^{86} \mathrm{Sr}=0.056505 \pm 40(2 \sigma \mathrm{SD})$ (Thirwall 1991, Ramos et al. 2004) and ${ }^{84} \mathrm{Sr} /{ }^{88} \mathrm{Sr}=0.00675$ (natural abundances ratio).
To further evaluate the effectiveness of the applied corrections, we plotted ${ }^{87} \mathrm{Sr} /{ }^{86} \mathrm{Sr}$ and ${ }^{84} \mathrm{Sr} /{ }^{86} \mathrm{Sr}$ ratios (Fig. 2b). The lack of correlation between the ratios indicates that variations in the ${ }^{87} \mathrm{Sr} /{ }^{86} \mathrm{Sr}$ are not due to analytical artifacts (Bizzarro et al. 2003), but instead represent real fluctuations in the measured radiogenic ratio.

\section{DISCUSSION}

\section{Background and $\mathrm{REE}^{+2}$ interferences}

One important implication of our results is that employment of a constant background value to a dataset is not advisable. Background levels vary significantly on a daily basis and as a function of the material ablated prior to a blank

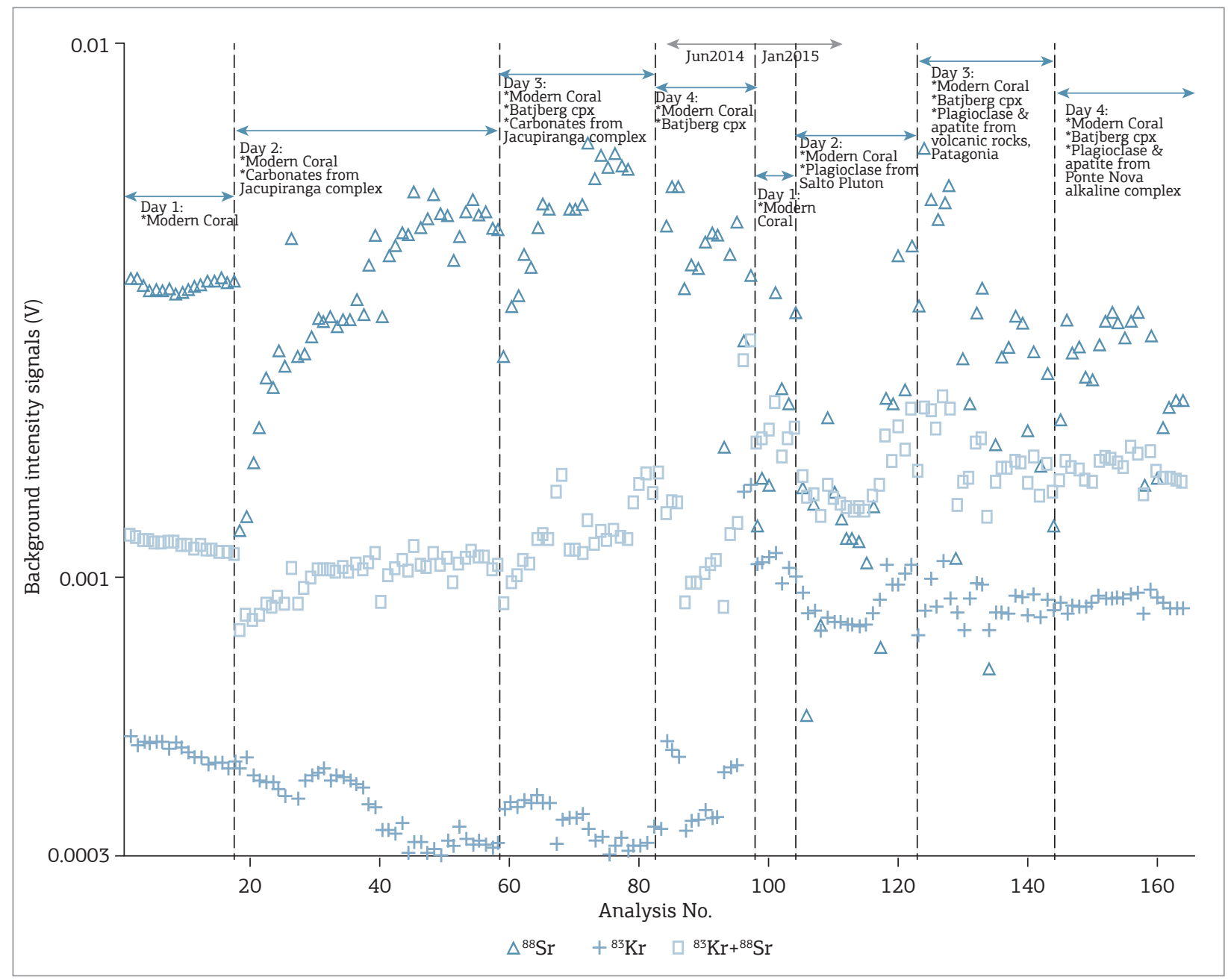

Figure 1. Background level measurements for stable $\mathrm{Sr}$ and $\mathrm{Kr}$ isotopes (83, 86 and 83 masses masses). Shaded areas mark different analytical days including both campaings that involved the ablation of different materials (note the steady behavior of the signals of Day 1 2014, when only carbonate is ablated). Background signals result from the accumulation of ${ }^{86} \mathrm{Kr}$ and ${ }^{86} \mathrm{Sr}$ from previous ablations. Points represent background measurements performed prior to each ablation. 


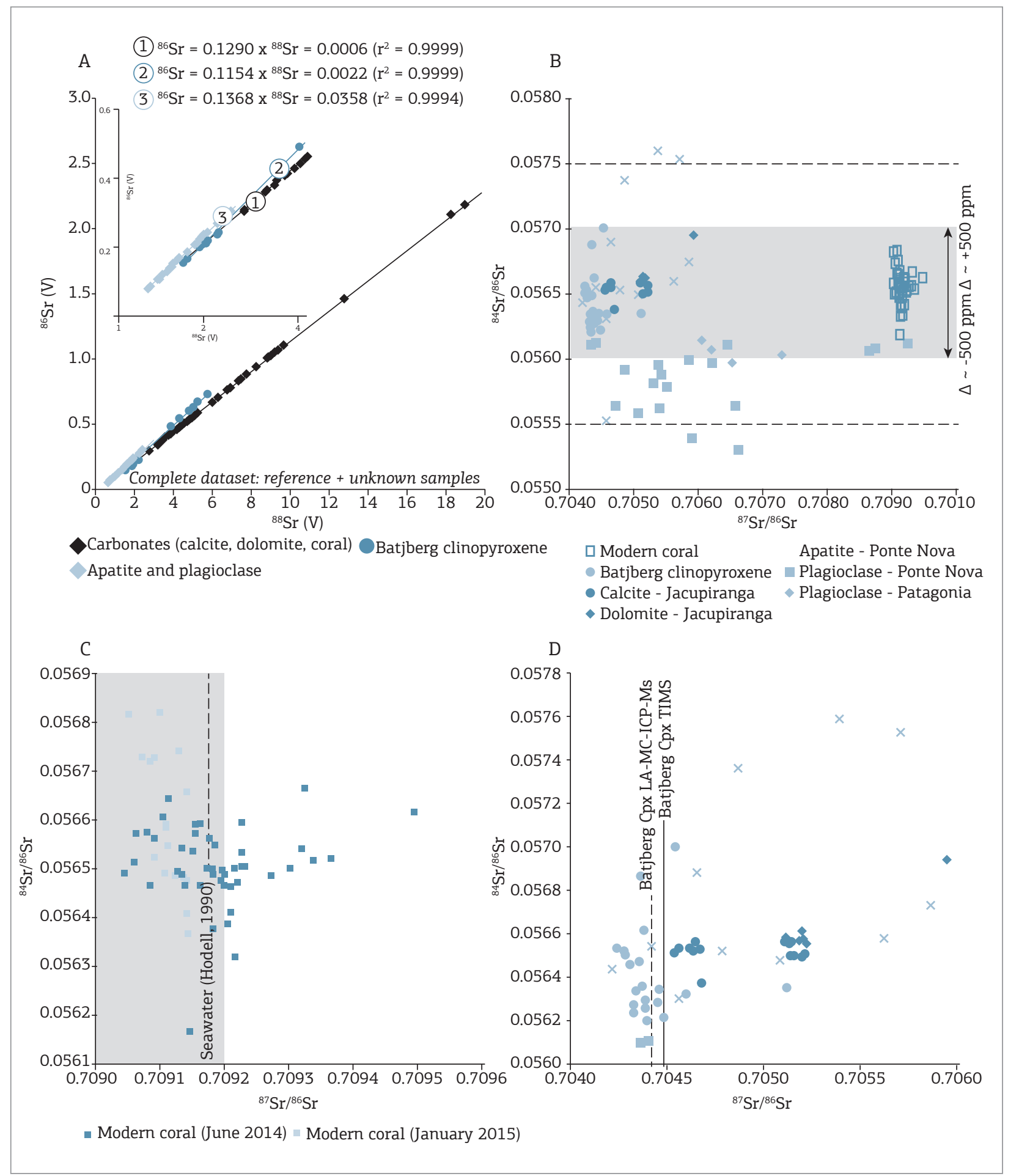

Figure 2. A) Average net ${ }^{88} \mathrm{Sr}$ versus ${ }^{86} \mathrm{Sr}$ intensities for all matrices. Three different trends can be identified: trend \#1 includes plagioclase and apatite results; trend \#2 are results from Batjberg clinopyroxene; and trend \#3 include all the analyzed carbonate (modern coral and unknowns).B) ${ }^{87} \mathrm{Sr} /{ }^{86} \mathrm{Sr}$ versus ${ }^{84} \mathrm{Sr} /{ }^{86} \mathrm{Sr}$ ratios for the whole dataset (except Salto pluton). Shaded area represents $\pm 500 \mathrm{ppm}$ from the accepted ${ }^{84} \mathrm{Sr} /{ }^{86} \mathrm{Sr}$ value. C) Zoomed version of the diagram in (B) highlighting results for the modern coral. Shaded area corresponds to reported literature values (Bizzarro et al. 2003 and Yang et al. 2011), whereas the dashed line represents Sr isotope composition of the modern seawater (0.709172, Hodell et al. 1990). D) Zoomed version of the diagram in (B) highlighting results for unknowns (magmatic carbonate and apatite) and the Batjberg clinopyroxene. ${ }^{87} \mathrm{Sr} /{ }^{86} \mathrm{Sr}$ ratios obtained via LA-MC-ICPMS and via TIMS are showed as dashed and continuous lines, respectively (data from Adams et al. 2005). 
measurement (Fig. 1). The variation observed for mass 86 reflects the interference of both $\mathrm{Kr}$ masses and residual $\mathrm{Sr}$ isotopes from previous ablations, a phenomenon also suggested by the lack of correlation between $\mathrm{Kr}$ masses. The resultant background counts implies that, apart from the Rb interference, the gas carrier is the most important interferant to be accounted for when analyzing Sr isotopes. Unfortunately, the evaluation of the Kr mass bias factor is not straightforward

Table 3. In situ Sr isotope analyses on reference samples according to diferent reduction protocols.

\section{(a) Modern coral}

(a.1) Range of net signal intensities (June 2104 and January 2105 campaigns)

\begin{tabular}{c|c|c|c|}
\hline${ }^{88} \mathrm{Sr}(\mathrm{V})$ & ${ }^{85} \mathrm{Rb}(\mathrm{mV})$ & ${ }^{173 \mathrm{Yb}^{2+}(\mathrm{mV})}$ & ${ }^{171} \mathrm{Yb}^{2+}\left(\mathrm{mV}^{2}\right)$ \\
\hline $2.6-30.6$ & $0.0110-0.162$ & $0.016-0.036$ & $0.017-0.051$ \\
\hline
\end{tabular}

(a.2) Average value for $\mathrm{Sr}$ isotopic ratios according reduction type ( $n=45)$. June 2014 database.

\begin{tabular}{|c|c|c|c|c|}
\hline Reduction type ${ }^{(b)}$ & ${ }^{87} \mathrm{Sr} /{ }^{86} \mathrm{Sr} \pm \mathrm{SD}(2 \sigma)$ & $\begin{array}{c}\Delta^{87} \mathrm{Sr} /{ }^{86} \mathrm{Sr} \times 10^{6} \mathrm{LA}- \\
\mathrm{REF} \text { value }\end{array}$ & ${ }^{84} \mathrm{Sr} /{ }^{86} \mathrm{Sr} \pm \mathrm{SD}(2 \sigma)$ & ${ }^{84} \mathrm{Sr} /{ }^{88} \mathrm{Sr} \pm \mathrm{SD}(2 \sigma)$ \\
\hline Type 0 & $0.709242 \pm 29$ & +70 & $0.056533 \pm 32$ & $0.006750 \pm 04$ \\
\hline Type 1 & $0.709192 \pm 31$ & +20 & $0.056505 \pm 30$ & $0.006747 \pm 04$ \\
\hline Type 2 & $0.709099 \pm 60$ & -73 & $0.056521 \pm 42$ & $0.006749 \pm 05$ \\
\hline Type 3 & $0.709214 \pm 62$ & +42 & $0.056593 \pm 53$ & $0.006758 \pm 07$ \\
\hline Type 4 & $0.709098 \pm 65$ & -74 & $0.056521 \pm 43$ & $0.006749 \pm 05$ \\
\hline Type 5 & $0.709182 \pm 33$ & +10 & $0.056502 \pm 31$ & $0.006745 \pm 04$ \\
\hline
\end{tabular}

(a.3) Average value for $\mathrm{Sr}$ isotopic ratios according reduction type 1 ( $n=20)$. January 2015 database.

Type 1

$-52$

$0.056569 \pm 59$

$0.006754 \pm 04$

\section{(b) Batjberg clinopyroxene}

(b.1) Range of net signal intensities (June 2104 and January 2105 campaigns)

\begin{tabular}{|c|c|c|c|c}
${ }^{8} \mathrm{Sr}(\mathrm{V})$ & ${ }^{85} \mathrm{Rb}(\mathrm{mV})$ & ${ }^{173} \mathrm{Yb}^{2+}(\mathrm{mV})$ & ${ }^{171} \mathrm{Yb}^{2+}(\mathrm{mV})$ & ${ }^{166} \mathrm{Er}^{2+}(\mathrm{mV})$ \\
\hline $1.4-5.7$ & $0.03-0.49$ & $0.015-0.031$ & $0.019-0.046$ & $0.014-0.042$ \\
\hline
\end{tabular}

(b.2) Average value for $\mathrm{Sr}$ isotopic ratios according reduction type $(\mathrm{n}=15)$

\begin{tabular}{|c|c|c|c|c|}
\hline Reduction type & ${ }^{87} \mathrm{Sr} /{ }^{86} \mathrm{Sr} \pm \mathrm{SD}(2 \sigma)$ & $\begin{array}{c}\Delta^{87} \mathrm{Sr} /{ }^{86} \mathrm{Sr} \times 10^{6} \mathrm{LA}- \\
\mathrm{REF} \text { value }{ }^{(a)}\end{array}$ & ${ }^{84} \mathrm{Sr} /{ }^{86} \mathrm{Sr} \pm \mathrm{SD}(2 \sigma)$ & ${ }^{84} \mathrm{Sr} /{ }^{88} \mathrm{Sr} \pm \mathrm{SD}(2 \sigma)$ \\
\hline Type 0 & $0.704588 \pm 114$ & +114 & $0.056574 \pm 189$ & $0.006755 \pm 22$ \\
\hline Type 1 & $0.704417 \pm 120$ & -57 & $0.056481 \pm 164$ & $0.006744 \pm 20$ \\
\hline Type 2 & $0.704375 \pm 159$ & -99 & $0.056474 \pm 182$ & $0.006744 \pm 24$ \\
\hline Type 3 & $0.703422 \pm 242$ & -1052 & $0.056283 \pm 511$ & $0.006685 \pm 112$ \\
\hline Type 4 & $0.704252 \pm 153$ & -222 & $0.056492 \pm 320$ & $0.006705 \pm 110$ \\
\hline Type 5 & $0.704437 \pm 096$ & -37 & $0.056481 \pm 175$ & $0.006743 \pm 24$ \\
\hline
\end{tabular}

(b.3) Average value for $\mathrm{Sr}$ isotopic ratios according reduction type 1 ( $n=6)$. January -2015 database

\begin{tabular}{l|l|l|l|l} 
Type 1 & $0.704435 \pm 058$ & -39 & $0.0565150 \pm 120$ & $0.0067505 \pm 21$
\end{tabular}

(a) The parameter $\Delta^{87} \mathrm{Sr} /{ }^{86} \mathrm{Sr} \mathrm{LA}$ - REF value was calculated by comparing the average ${ }^{87} \mathrm{Sr} /{ }^{86} \mathrm{Sr}$ value with reference composition for each reference material. The ${ }^{87} \mathrm{Sr} /{ }^{86} \mathrm{Sr}$ composition of present - day seawater $(0.709172$, Hodell et al., 1990) was considered as reference for coral. In addition, the average TIMS ${ }^{87} \mathrm{Sr} /{ }^{86} \mathrm{Sr}$ value of $0.704474 \pm 17(2 \sigma \mathrm{SD})$ reported by Adams et al. (2005) was considered as reference for Batjberg clinopyroxene LA analysis. This parameter is expressed in ppm.

(b) Preferred reduction types are highlighted in bold

(c) $2 \sigma$ standard deviations and errors are given in relation to the last decimal digits 
and a ßKr-based method for the correction of blank levels might be challenging (McCulloch et al. 2005).

Our results suggest the feasibility of using the OPZ method to successfully account for the gas contribution to the Sr isotopes, since the data shows no correlation between $\mathrm{Sr}$ isotope ratios versus $\mathrm{Sr} / \mathrm{Kr}$ (not shown).

Variable $\beta Y \mathrm{Yb}$ values probably reflect the variation of the isobaric interferences over short timescales for the different minerals being ablated. Note that the total $\mathrm{BY}$ variation regards reference and unknown materials, likely to bear different REE contents.

\section{Validation of the method}

The accuracy and external reproducibility of the $\mathrm{Sr}$ isotope ratios have been invoked as the main parameters determining the effectiveness of Sr LA-MC-ICP-MS protocols. According to Vroon et al. (2008), accuracy is more important than precision. Since Sr stable isotope ratios are material-independent, the comparison between acquired ${ }^{84} \mathrm{Sr} /{ }^{86} \mathrm{Sr}$ and ${ }^{84} \mathrm{Sr} /{ }^{88} \mathrm{Sr}$ isotope ratios with their accepted values is the most reliable tool for the validation of the technique. Our individual ${ }^{84} \mathrm{Sr} /{ }^{86} \mathrm{Sr}$ determinations define deviations from true values in the range of 1 to $200 \mathrm{ppm}$ for the modern coral and Batjberg Fe-rich clinopyroxene (reductions types 1 and 5, Table 2, grey area in Fig. 2B). Such deviations are smaller than those obtained by Ramos et al. (2004), which range from 60 to $350 \mathrm{ppm}$ for modern marine carbonate, clinopyroxene and plagioclase analyses.

For the unknowns, the majority of ${ }^{84} \mathrm{Sr} /{ }^{86} \mathrm{Sr}$ deviate $\pm 500 \mathrm{ppm}$ from the accepted value (0.00565, Thirwall 1991, Fig. 2B grey area). Compared with available studies, these results represent an accuracy improvement, since deviations in ${ }^{84} \mathrm{Sr} /{ }^{86} \mathrm{Sr}$ obtained in carbonates and clinopyroxenes can reach up to $12,000-14,000 \mathrm{ppm}$ (Vroon et al. 2008).

The ${ }^{84} \mathrm{Sr} /{ }^{86} \mathrm{Sr}$ ratios from plagioclase crystals are 400 to $1200 \mathrm{ppm}$ lower than the accepted value (Fig. 2B), which might explain the higher ${ }^{86} \mathrm{Sr} /{ }^{88} \mathrm{Sr}$ ratios $(\sim 0.1368$ against the accepted ratio 0.1194, trend 3 in Fig. 2A). Kimura et al. (2013) found similar results for unknown determinations and for a plagioclase standard (Miyakejima anorthite) and argued that such problems did not lead to erroneous ${ }^{87} \mathrm{Sr} /{ }^{86} \mathrm{Sr}$ determinations, given that acquired ratios were close to those determined by TIMS.

Considering both analytical sessions, accuracy on ${ }^{87} \mathrm{Sr} /{ }^{86} \mathrm{Sr}$ range from 37 to 57 ppm for both reference materials (modern coral and Batjberg clinopyroxene) and these are similar to values obtained in other studies employing similar standards (between 57 and 70 ppm, e.g.,, Bizarro et al. 2003, Schmidberger et al. 2003, Ramos et al. 2004, Woodhead et al. 2005, Yang et al. 2011).

\section{Potential instrumental-related artifacts}

Instrument-induced fractionation and low Sr contents might severely affect both accuracy and $2 \sigma$ external reproducibilities. The lack of correlation between ${ }^{84} \mathrm{Sr} /{ }^{86} \mathrm{Sr}$ and ${ }^{87} \mathrm{Sr} /{ }^{86} \mathrm{Sr}$ strongly argues in favour of negligible instrumental influence on measured $\mathrm{Sr}$ isotopic ratios (see complete dataset in Figs. 2B, 2C, 2D) (e.g., Bizarro et al. 2003).

The potential influence of the amplifier response on the precision of the measured $\mathrm{Sr}$ isotope ratios has been rarely mentioned in literature (e.g., McFarlane \& McCulloch 2008, Yang et al. 2011). McFarlane \& McCulloch (2008) used a fixed collector-amplifier array that resulted ${ }^{87} \mathrm{Sr} /{ }^{86} \mathrm{Sr}$ ratios with internal (within-run) errors between \pm 0.000080 to \pm 0.000200 ( $2 \sigma$ SE). Conversely, Yang et al. (2011) employed amplifiers sequentially connected to all Faraday cups that

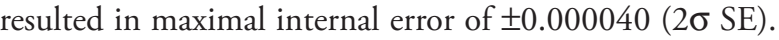
Our ${ }^{87} \mathrm{Sr} /{ }^{86} \mathrm{Sr}$ determinations in reference materials show within-run errors between \pm 0.000005 and $0.000077(2 \sigma$ $\mathrm{SE}$ ), endorsing the feasibility of sequential Faraday cup-amplifier connections.

\section{Applications to petrogenetical problems}

The following sections present $\mathrm{Sr}$ isotope compositions determined on calcite, dolomite, apatite and plagioclase crystals from a variety of geological contexts. The analytical procedure is identical to the presented earlier, and reduction protocol Type 1 was used in all cases. It is worth mentioning that the spot size, laser pulse energy, as well as laser frequency, were variable in order to optimize the ablation and $\mathrm{Sr}$ signal $\left({ }^{88} \mathrm{Sr}\right.$ signals $<1 \mathrm{~V}$ were not considered) as a function of the material characteristics. Table 4 summarizes the average $\mathrm{Sr}$ isotope determinations on unknown samples.

\section{Carbonatites from the Jacupiranga Complex}

The Jacupiranga alkaline - carbonatitic complex belongs to an Early Cretaceous group of complexes $(-130-133 \mathrm{Ma})$ located in the border of the Paraná basin, southern Brazil. These complexes are composed of intrusive carbonatites spatially associated with alkaline mafic rocks. Previous geochemical studies indicate either a contribution from the Tristan mantle plume to carbonatite genesis (Huang et al. 1995), or a generation from lithospheric mantle regions (CominChiaramonti et al. 2005).

We analyzed magmatic carbonate minerals from carbonatite samples of the Jacupiranga complex (22 grains, 1 analysis/grain). The spot size was constant at $120 \mu \mathrm{m}$, with pulse energy of $6-7 \mathrm{~mJ}$ and a frequency of $10 \mathrm{~Hz}$. Studied carbonate grains $(\mathrm{n}=22)$ were hand-picked from different carbonatite samples: 7 calcite grains from an apatite-rich sövite (C1 sample), 6 calcite and 2 dolomite grains from a 
calcite-rich sövite (C2 sample), and 2 calcite and 5 dolomite grains from a dolomite-rich sövite (C3 sample).

Individual ${ }^{84} \mathrm{Sr} /{ }^{86} \mathrm{Sr}$ compositions ranged from $0.056248 \pm$ $52(2 \sigma \mathrm{SE})$ to $0.056931 \pm 41(2 \sigma \mathrm{SE})$ for magmatic carbonate. Individual ${ }^{84} \mathrm{Sr} /{ }^{88} \mathrm{Sr}$ values varied between $0.006716 \pm 6$ and $0.006798 \pm 6(2 \sigma \mathrm{SE})$. Therefore, invariant ratios are similar to the accepted values, supporting the validity the variations measured in radiogenic ratios.

In situ ${ }^{87} \mathrm{Sr} /{ }^{86} \mathrm{Sr}$ determinations in calcite and dolomite crystals show a coherent behavior with restricted variation $(0.7044$ to 0.7051 , Fig. 3$)$ and yielded an average ${ }^{87} \mathrm{Sr} /{ }^{86} \mathrm{Sr}$ ratio of $0.705031 \pm 89(2 \sigma \mathrm{SD})$, which is lower than previous isotopic signatures data for nephelinite whole-rock samples from Jacupiranga, Juquiá and Anitápolis complexes $\left({ }^{87} \mathrm{Sr} /{ }^{86} \mathrm{Sr} 0.70612-0.70754\right.$; Comin-Chiaramonti et al. 2005). Although slightly less radiogenic, these values are comparable to data obtained previously on apatite crystals from the same samples $(0.7050-0.7052$; Montecinos et al. 2014).

We do not interpret more radiogenic Sr isotope values to result from crustal contamination processes, because the high Sr contents observed in Brazilian carbonatites (2000 5700 ppm reported for carbonatites from southern Brazil) are in great excess to crustal abundances, suggesting that $\mathrm{Rb} /$ Sr ratios would be buffered at low values (i.e., contamination would have to be very extensive to produce noticeable changes on $\mathrm{Sr}$ isotope ratios).

Sr isotope variation observed in Jacupiranga indicates an origin through mixing of varied mantle sources. The similarities between Jacupiranga geochemical signatures and EM1 Atlantic-OIBs suggests a possible sub-lithospheric mantle source involving a mantle plume contribution on the studied carbonatites, coherently with the model suggested by Bell \& Simonetti (2010).

\section{The Ponte Nova mafic-ultramafic alkaline massif}

The Ponte Nova mafic-ultramafic alkaline massif (87.6 Ma; $22^{\circ} 47^{\prime}$ S, $45^{\circ} 45^{\prime} \mathrm{W}$; Azzone et al. 2009) is part of MesozoicCenozoic continental alkaline-carbonatite magmatism that occurs in the southeastern portion of the South American Platform.

The massif represents an alkaline gabbro association formed by successive magmatic pulses (Fig. 4a). The cumulatic central and western intrusions were comprised by similar lower sequences, characterized by olivine clinopyroxenites and olivine melagabbros, and different upper sequences, formed by porphyritic and equigranular gabbros and monzogabbros, and by banded nepheline-bearing gabbroic rocks, respectivelly. The cumulatic northern intrusion present olivine melamonzogabbros and olivine-bearing melamonzogabbros.
The eastern intrusion has inequigranular seriate to porphyritic nepheline-bearing monzodiorites. The southern intrusion has porphyritic nepheline-bearing melamonzonites (predominant rocks) and nepheline-bearing monzonites

A shift towards more radiogenic whole-rock Sr signatures from lower to upper sequences was found for the main cumulatic intrusions of the massif (Azzone 2008). These signatures indicate that the pluton evolved through concurrent fractional crystallization and assimilation processes (AFC).

In the Ponte Nova massif, Sr is mainly hosted in plagioclase and apatite (Azzone 2008). In cumulate intrusions, plagioclase and apatite are found locally as minor cumulus phases, but mainly as part of intercumulus material. In inequigranular intrusions, plagioclase and apatite are mainly found as matrix important phases, but as occasional macrocrysts too.

Plagioclase and apatite crystals from the most primitive samples of each intrusion were selected to evaluate possible nonequilibrium isotopic conditions. Results are summarized in Figure 4 and confirm the AFC process suggested by whole rock isotope analyses. Another manuscript will

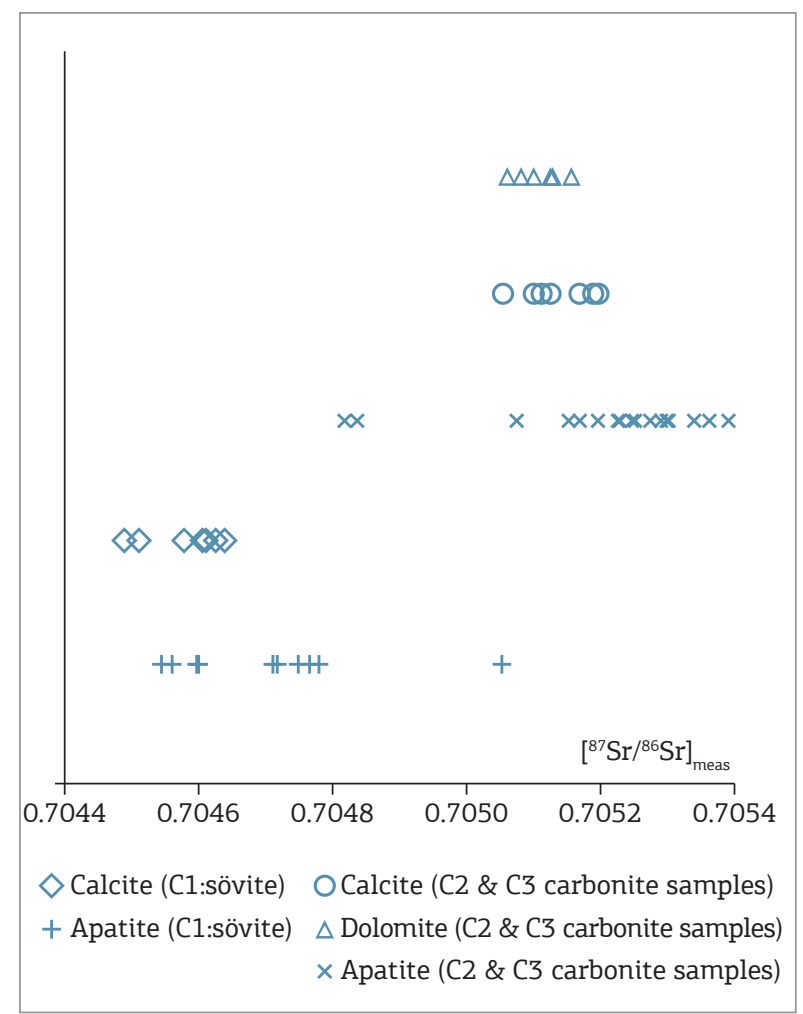

Figure 3. Plot of $\mathrm{Sr}$ isotope ratios on minerals from Jacupiranga complex. Sr isotopic compositions on apatite (Montecinos et al. 2014) were obtained in a LA-MC-ICP-MS instrument at University of Notre Dame (US). For all plotted individual data the average $2 \sigma$ standard error is lower than $0.003 \%$. 
Table 4. Synthesis of in situ Sr isotope analyses of the unknown samples.

\begin{tabular}{|c|c|c|c|c|c|c|c|c|c|}
\hline \multirow{3}{*}{ Geological unit } & \multirow{3}{*}{$\begin{array}{l}\text { Sample } \\
\text { rock }\end{array}$} & \multirow{3}{*}{ Mineral } & \multirow{2}{*}{\multicolumn{2}{|c|}{$\begin{array}{c}\begin{array}{c}\text { Range of individual } \\
{ }^{87} \mathrm{Sr} /{ }^{86} \mathrm{Sr} \text { values }\end{array} \\
{ }^{87} \mathrm{Sr} /{ }^{86} \mathrm{Sr} \pm 2 \sigma \mathrm{SE} \\
\end{array}$}} & \multirow{3}{*}{ 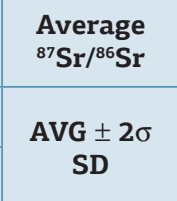 } & \multirow{3}{*}{ 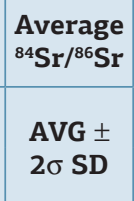 } & \multirow{3}{*}{$\begin{array}{c}\begin{array}{c}\text { Average } \\
{ }^{84} \mathrm{Sr} /{ }^{88} \mathrm{Sr}\end{array} \\
\begin{array}{l}\mathrm{AVG} \pm \\
2 \sigma \mathrm{SD}\end{array} \\
\end{array}$} & \multicolumn{2}{|c|}{$\begin{array}{c}\text { Range of net } \\
\text { signal intensities }\end{array}$} \\
\hline & & & & & & & & \multirow{2}{*}{${ }^{88} \mathrm{Sr}(\mathrm{V})$} & \multirow{2}{*}{${ }^{85} \mathrm{Rb}(\mathrm{mV})$} \\
\hline & & & Min & $\operatorname{Max}$ & & & & & \\
\hline \multirow{5}{*}{$\begin{array}{l}\text { aJacupiranga } \\
\text { carbonatites ( 130 } \\
\text { Ma, Southern Brazil) }\end{array}$} & $\begin{array}{l}\mathrm{C} 1- \\
\text { sovite }\end{array}$ & Calcite $(n=7)^{*}$ & $\begin{array}{c}0.704538 \\
\pm 32\end{array}$ & $\begin{array}{l}0.704695 \\
\quad \pm 28\end{array}$ & $0.704575 \pm 46$ & $\begin{array}{c}0.056513 \\
\pm 23\end{array}$ & $\begin{array}{c}0.006747 \\
\pm 06\end{array}$ & $6.2-8.9$ & $0.02-0.03$ \\
\hline & $\begin{array}{l}\mathrm{C} 2- \\
\text { sovite }\end{array}$ & Calcite $(n=6)$ & $\begin{array}{c}0.705122 \\
\pm 33\end{array}$ & $\begin{array}{l}0.705203 \\
\quad \pm 29\end{array}$ & $0.705150 \pm 22$ & $\begin{array}{c}0.056500 \\
\pm 42\end{array}$ & $\begin{array}{c}0.006749 \\
\pm 05\end{array}$ & $7.7-9.6$ & $0.01-0.03$ \\
\hline & $\begin{array}{l}\text { C3- } \\
\text { sovite }\end{array}$ & Calcite $(n=2)$ & $\begin{array}{c}0.705168 \\
\pm 30\end{array}$ & $\begin{array}{l}0.705199 \\
\quad \pm 28\end{array}$ & $* *$ & $\begin{array}{c}0.056493 \\
\pm 19\end{array}$ & $\begin{array}{c}0.006745 \\
\pm 02\end{array}$ & $9.0-9.1$ & $0.01-0.03$ \\
\hline & $\begin{array}{l}\mathrm{C} 2- \\
\text { sovite }\end{array}$ & Dolomite $(n=2)$ & $\begin{array}{l}0.705060 \\
\pm 65\end{array}$ & $\begin{array}{l}0.705099 \\
\quad \pm 52\end{array}$ & $* *$ & $\begin{array}{c}0.056579 \\
\pm 41\end{array}$ & $\begin{array}{c}0.006755 \\
\pm 06\end{array}$ & $3.7-4.0$ & $0.03-0.05$ \\
\hline & $\begin{array}{l}\mathrm{C} 2- \\
\text { sovite }\end{array}$ & Dolomite $(n=6)$ & $\begin{array}{c}0.705126 \\
\pm 70\end{array}$ & $\begin{array}{l}0.705884 \\
\quad \pm 70\end{array}$ & $0.705126 \pm 64$ & $\begin{array}{c}0.056593 \\
\pm 43\end{array}$ & $\begin{array}{c}0.006755 \\
\pm 05\end{array}$ & $3.7-4.3$ & $0.01-0.05$ \\
\hline \multirow{2}{*}{$\begin{array}{l}\text { Chacays - Patagonia } \\
\text { Argentina ( } 25 \mathrm{Ma})\end{array}$} & \multirow{2}{*}{$\begin{array}{l}\text { AN35 - } \\
\text { Trachyte }\end{array}$} & $\begin{array}{c}\text { Plagioclase }(n=4) \\
\text { Core }+ \text { preserved } \\
\text { rims }\end{array}$ & $\begin{array}{c}0.706049 \\
\pm 73\end{array}$ & $\begin{array}{c}0.707307 \pm \\
170\end{array}$ & $* * *$ & $\begin{array}{c}0.056034 \\
\pm 452\end{array}$ & $\begin{array}{c}0.006689 \\
\pm 61\end{array}$ & $1.7-2.1$ & $2.2-5.8$ \\
\hline & & Apatite $(n=2)$ & $\begin{array}{c}0.706674 \\
\pm 763\end{array}$ & $\begin{array}{c}0.708618 \pm \\
631\end{array}$ & ** & $\begin{array}{c}0.056165 \\
\pm 400\end{array}$ & $\begin{array}{c}0.006706 \\
\pm 47\end{array}$ & $0.4-0.5$ & $1.4-2.0$ \\
\hline \multirow{9}{*}{$\begin{array}{l}\text { Ponte Nova mafic- } \\
\text { ultramafic alcaline } \\
\text { massif } \\
(\sim 86.7 \mathrm{Ma} \text {, Southern } \\
\text { Brazil) }\end{array}$} & $\begin{array}{l}\text { 165a- } \\
\text { ESI }\end{array}$ & Plagioclase $(n=2)$ & $\begin{array}{c}0.705440 \\
\pm 70\end{array}$ & $\begin{array}{l}0.706454 \\
\quad \pm 71\end{array}$ & $* *$ & $\begin{array}{c}0.055987 \\
\pm 059\end{array}$ & $\begin{array}{c}0.006685 \\
\pm 07\end{array}$ & $2.0-2.2$ & $0.4-1.5$ \\
\hline & 41a- NSI & Plagioclase $(n=5)$ & $\begin{array}{c}0.704410 \\
\pm 75\end{array}$ & $\begin{array}{c}0.706643 \pm \\
251\end{array}$ & $* * *$ & $\begin{array}{c}0.005594 \\
\pm 170\end{array}$ & $\begin{array}{c}0.006670 \\
\pm 35\end{array}$ & $0.6-1.8$ & $0.03-1.0$ \\
\hline & $117 a-C I$ & Plagioclase $(n=5)$ & $\begin{array}{c}0.704851 \\
\pm 106\end{array}$ & $\begin{array}{c}0.705535 \pm \\
124\end{array}$ & $\begin{array}{c}0.705240 \pm \\
124\end{array}$ & $\begin{array}{c}0.055740 \\
\pm 260\end{array}$ & $\begin{array}{c}0.006654 \\
\pm 16\end{array}$ & $0.9-1.0$ & $0.4-0.7$ \\
\hline & 58a-WI & Plagioclase $(n=3)$ & $\begin{array}{c}0.705849 \\
\pm 86\end{array}$ & $\begin{array}{l}0.706585 \\
\quad \pm 90\end{array}$ & $* * *$ & $\begin{array}{c}0.055670 \\
\pm 390\end{array}$ & $\begin{array}{c}0.006645 \\
\pm 47\end{array}$ & $0.9-1.6$ & $0.2-0.5$ \\
\hline & $180-S S A$ & Plagioclase $(n=5)$ & $\begin{array}{c}0.705499 \\
\pm 113\end{array}$ & $\begin{array}{c}0.709268 \pm \\
105\end{array}$ & $* * *$ & $\begin{array}{c}0.056044 \\
\pm 063\end{array}$ & $\begin{array}{c}0.006692 \\
\pm 07\end{array}$ & $1.3-2.0$ & $0.6-4.6$ \\
\hline & $\begin{array}{l}\text { 165a- } \\
\text { ESI }\end{array}$ & Apatite $(n=3)$ & $\begin{array}{c}0.704792 \\
\pm 85\end{array}$ & $\begin{array}{l}0.705083 \\
\pm 86\end{array}$ & $\begin{array}{c}0.704910 \pm \\
190\end{array}$ & $\begin{array}{c}0.056780 \\
\pm 044\end{array}$ & $\begin{array}{c}0.006780 \\
\pm 06\end{array}$ & $1.9-2.4$ & $0.04-0.2$ \\
\hline & 41a- NSI & Apatite $(n=4)$ & $\begin{array}{c}0.704217 \\
\pm 91\end{array}$ & $\begin{array}{c}0.704660 \pm \\
195\end{array}$ & $\begin{array}{c}0.704450 \pm \\
200\end{array}$ & $\begin{array}{c}0.056540 \\
\pm 270\end{array}$ & $\begin{array}{c}0.006751 \\
\pm 32\end{array}$ & $1.4-3.1$ & $0.1-0.2$ \\
\hline & $117 a-C I$ & Apatite $(n=2)$ & $\begin{array}{c}0.704580 \\
\pm 156\end{array}$ & $\begin{array}{c}0.704731 \pm \\
135\end{array}$ & $* *$ & $\begin{array}{c}0.055450 \\
\pm 140\end{array}$ & $\begin{array}{c}0.006620 \\
\pm 17\end{array}$ & $0.6-0.7$ & $0.1-0.2$ \\
\hline & 58a-WI & Apatite $(n=4)$ & $\begin{array}{c}0.705390 \\
\pm 177\end{array}$ & $\begin{array}{c}0.705866 \pm \\
138\end{array}$ & $\begin{array}{c}0.705660 \pm \\
200\end{array}$ & $\begin{array}{c}0.057110 \\
\pm 560\end{array}$ & $\begin{array}{c}0.006821 \\
\pm 69\end{array}$ & $1.1-1.2$ & $0.03-0.2$ \\
\hline \multirow{4}{*}{$\begin{array}{l}\text { Salto pluton, Itu } \\
\text { Igneous Province ( } 585 \\
\text { Ma, Southern Brazil) }\end{array}$} & $\begin{array}{c}\text { ITU. } \\
\text { FME.3_2 }\end{array}$ & Plagioclase $(n=6)$ & $\begin{array}{c}0.708715 \\
\pm 136\end{array}$ & $\begin{array}{c}0.7109553 \\
\pm 213\end{array}$ & $* * *$ & $\begin{array}{c}0.055435 \\
\pm 038\end{array}$ & $\begin{array}{c}0.006559 \\
\pm 44\end{array}$ & $\begin{array}{c}0.98- \\
1.25\end{array}$ & $3.31-5.93$ \\
\hline & $\begin{array}{c}\text { ITU } \\
\text { FME1_8 }\end{array}$ & Plagioclase $(n=3)$ & 0.711334 & 0.7222389 & $* * *$ & $\begin{array}{c}0.554352 \\
\pm 177 \\
\end{array}$ & $\begin{array}{c}0.006652 \\
\pm 211\end{array}$ & $0.8-1.6$ & $1.99-4.70$ \\
\hline & $\begin{array}{c}\text { ITU_- } \\
\text { MME2.1C }\end{array}$ & Plagioclase $(n=5)$ & 0.706278 & 0.714802 & $* * *$ & $\begin{array}{c}0.055734 \\
\pm 040\end{array}$ & $\begin{array}{c}0.006635 \\
\pm 070\end{array}$ & $\begin{array}{c}1.04- \\
2.68\end{array}$ & $2.54-24.9$ \\
\hline & $\begin{array}{c}\text { ITU_ } \\
\text { host27D }\end{array}$ & Plagioclase $(n=10)$ & 0.709385 & 0.714802 & $* * *$ & $\begin{array}{c}0.055329 \\
\pm 118\end{array}$ & $\begin{array}{c}0.006618 \\
\pm 032\end{array}$ & $\begin{array}{l}0.4- \\
1.15\end{array}$ & $2.05-10.1$ \\
\hline
\end{tabular}

Notes: * $\mathrm{n}$ denote number of analyses each obtained in different grains.

${ }^{* *}$ For samples with two analyse were not calculated average value for ${ }^{87} \mathrm{Sr} /{ }^{86} \mathrm{Sr}$ ratio.

${ }^{* * *}$ Average values were not calculated for samples with great variation of individual ${ }^{87} \mathrm{Sr} /{ }^{86} \mathrm{Sr}$ ratios.

a Jacupiranga samples were analized during the first analytical campaign (June 2014). The remaining samples were analyzed in January 2015. 
explore the complete petrological implications of isotopic data for this massif. The large ranges in $\mathrm{Sr}$ isotopic ratios recorded by apatite and plagioclase crystals indicate extensive isotopic changes during fractional crystallization stages of each intrusion. These ranges show lower ${ }^{87} \mathrm{Sr} /{ }^{86} \mathrm{Sr}$ compositions in the early crystallization stages, with a gradual evolution towards a higher ${ }^{87} \mathrm{Sr} /{ }^{86} \mathrm{Sr}$ ratio component in the later stages.

One implication of our results is that intercumulus materials were not efficiently trapped in the cumulus piles, but instead remained connected with the surrounding contaminated magma. This interpretation would have benefited from determination of $\mathrm{Sr}$ isotopes in pyroxene crystals with resorbed cores overgrown by chemically distinct rims, but low $\mathrm{Sr}$ contents prevented the acquisition of accurate ${ }^{87} \mathrm{Sr} /{ }^{86} \mathrm{Sr}$ ratios.
Plagioclase xenocrysts from microgranitoid enclaves of the Salto pluton (Itu Igneous Province)

The Salto pluton is part of the Itu Batholith, which is the most extensive volume of granitic rocks in the post-orogenic Itu Granite Province, São Paulo, Brazil (Fig. 5a). For details on the geology of the pluton, including the petrographic description of the different enclave types, the reader is referred to Alves et al. (2015).

Petrographic studies in both enclave types reveal the ubiquitous presence of plagioclase xenocrysts whose appearance, orientation and composition are similar to those observed in the host granites. Thus, tracking the isotope variation in plagioclase crystals is of key importance to determine enclave origin and chamber dynamics (e.g., Alves et al. 2009, Braschi et al. 2014).

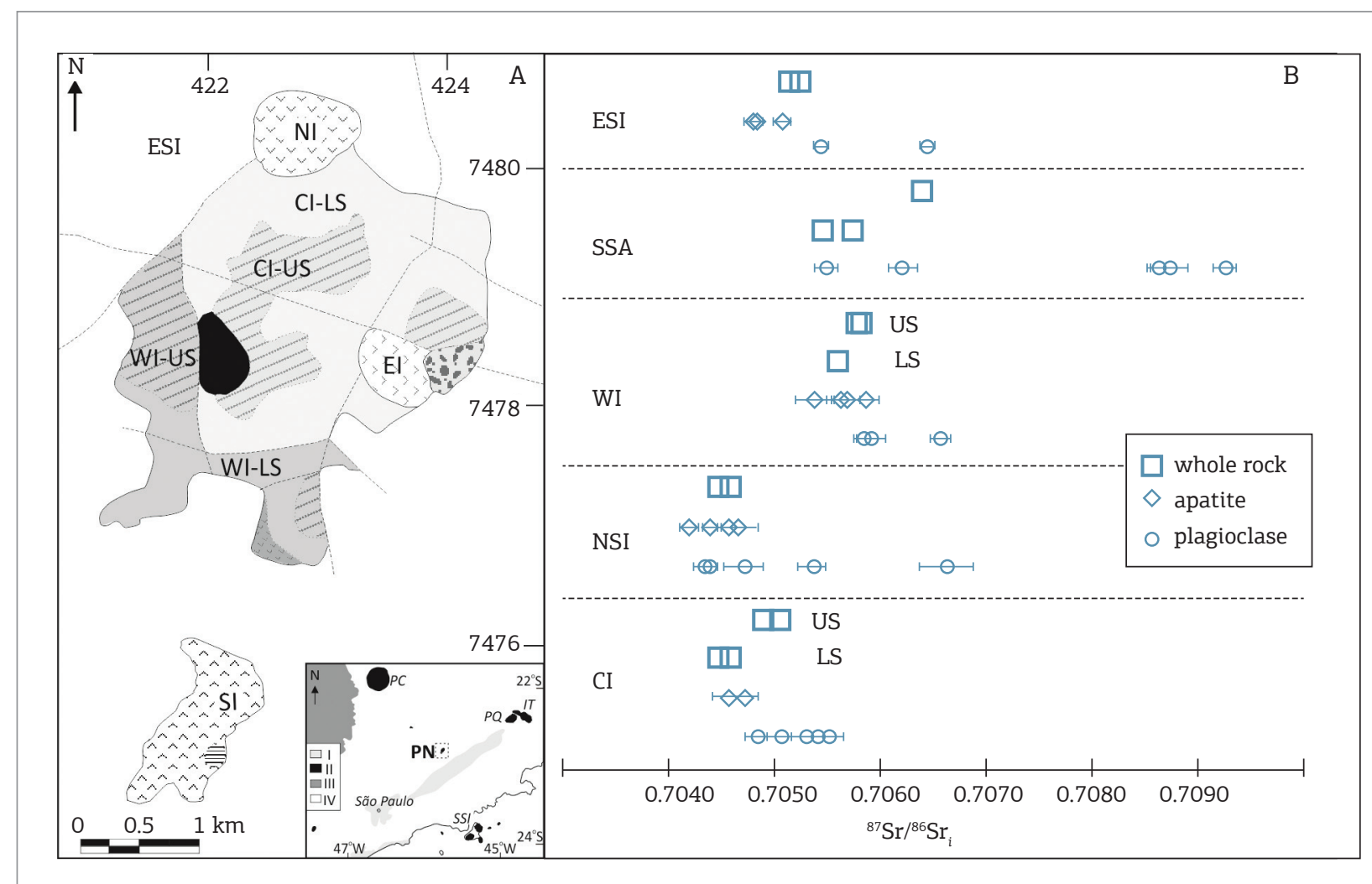

Figure 4. (A) Geological map of the Ponte Nova mafic-ultramafic alkaline massif (simplified from Azzone et al. 2009). CI - central intrusion; WI - western intrusion; NI - northern intrusion; EI - eastern intrusion; SI - southern intrusion; LS - lower sequence; US - upper sequence (see text for more information). Inset: Location and geological setting of the main alkaline intrusions of Mesozoic-Cenozoic magmatism in the southeastern part of South American Platform: PC - Poços de Caldas; PQ - Passa Quatro; IT - Itatiaia; SSI - São Sebastião Island; PN - Ponte Nova. I. Sediments or sedimentary rocks associated with rift basins (Cenozoic); II: Alkaline complexes (MesoCenozoic); III: Sedimentary rocks of the Paraná Basin (Ordovician-Silurian); IV: Crystalline Basement, Brasília and Ribeira orogenic belts (Precambrian). Simplified from Schobbenhauss et al. (2004). B) ${ }^{87} \mathrm{Sr}^{86}{ }^{8} \mathrm{Sr}_{i}$ ratios for whole rock and minerals from the different intrusions of the Ponte Nova Massif (Azzone et al., 2016). Horizontal bars in mineral analysis are indicative of $2 \sigma \mathrm{SE}$. 
The acquisition of accurate ${ }^{87} \mathrm{Sr} /{ }^{86} \mathrm{Sr}$ is hindered by a pervasive hydrothermal alteration that affects most of the crystals. Nevertheless, age-corrected ${ }^{87} \mathrm{Sr} /{ }^{86} \mathrm{Sr}$ ratios are almost identical to uncorrected data, arguing in favor of a minor $\mathrm{Rb}$ interference and, moreover, indicate that the obtained ratios represent the initial Sr isotope ratios of the magmas in equilibrium with different growth regions of the plagioclase crystals.

When appreciated together, data from host granites, felsic and a mafic micrograitoid enclave (MME, Fig. 5b) define a broad, but similar, ${ }^{87} \mathrm{Sr} /{ }^{86} \mathrm{Sr}$ variation. The rims from MME plagioclase crystals define the less radiogenic values of the pluton, and these are preceeded by strongly radiogenic cores, a scenario identical to the observed for the FME, except that rims values are subtly less radiogenic compared to the MMEs. Conversely, plagioclase phenocrysts analyzed from the host granites show an inverse fashion, since core regions are less radiogenic than rims, with an overall tendency for more radiogenic values compared to both enclave types. Since a thorough investigation on the implications of the isotope variations is being prepared in a separate contribution, results are only summarized in Figure $7 \mathrm{~b}$. From the spreading observed in $\mathrm{Sr}$ isotope ratios, we conclude that enclave plagioclase xenocrysts register an open-system evolution process, where mixing events took place close to the chamber walls and replenishment batches disrupted contaminated early-formed cumulates in a scenario similar to that proposed by Alves et al. (2009). Contaminated plagioclase cores were either overgrown by rims in isotope equilibrium with enclave-forming magmas, or the gradual rimward decrease observed in $\mathrm{Sr}$ isotope ratios are a product of diffusion after crystal entrapment. The observed signatures for host granites phenocrysts are compatible to a chamber evolution via AFC processes.

It notewhorty that except for two results from the MME, all the remaing data show low ${ }^{84} \mathrm{Sr} /{ }^{86} \mathrm{Sr}$ and ${ }^{84} \mathrm{Sr} /{ }^{88} \mathrm{Sr}$ ratios compared to the reference values (average of $0.0552 \pm$ $0.00072 \sigma \mathrm{SD}$ and $0.00658 \pm 0.000092 \sigma \mathrm{SD}$ respectively). Vroon et al. (2008) attributes anomalous stable Sr isotope ratios to the interference of calcium dimers and argides in low $\mathrm{Sr} / \mathrm{Ca}$ mineral phases. The interference might be corrected by performing a 82 mass peak striping. In any case, results obtained in plagioclase crystals from Salto pluton are comparable to those acquired in similar plagioclase studies (e.g., Alves et al. 2009, Kimura et al. 2013) and are considered reliable trackers of the magma evolutionary process.

\section{Volcanic rocks from Somún Curá Plateau, Central Patagonia, Argentina}

Isotopic Sr data were determined on two plagioclase and two apatite crystals from thin sections from a trachyte sample

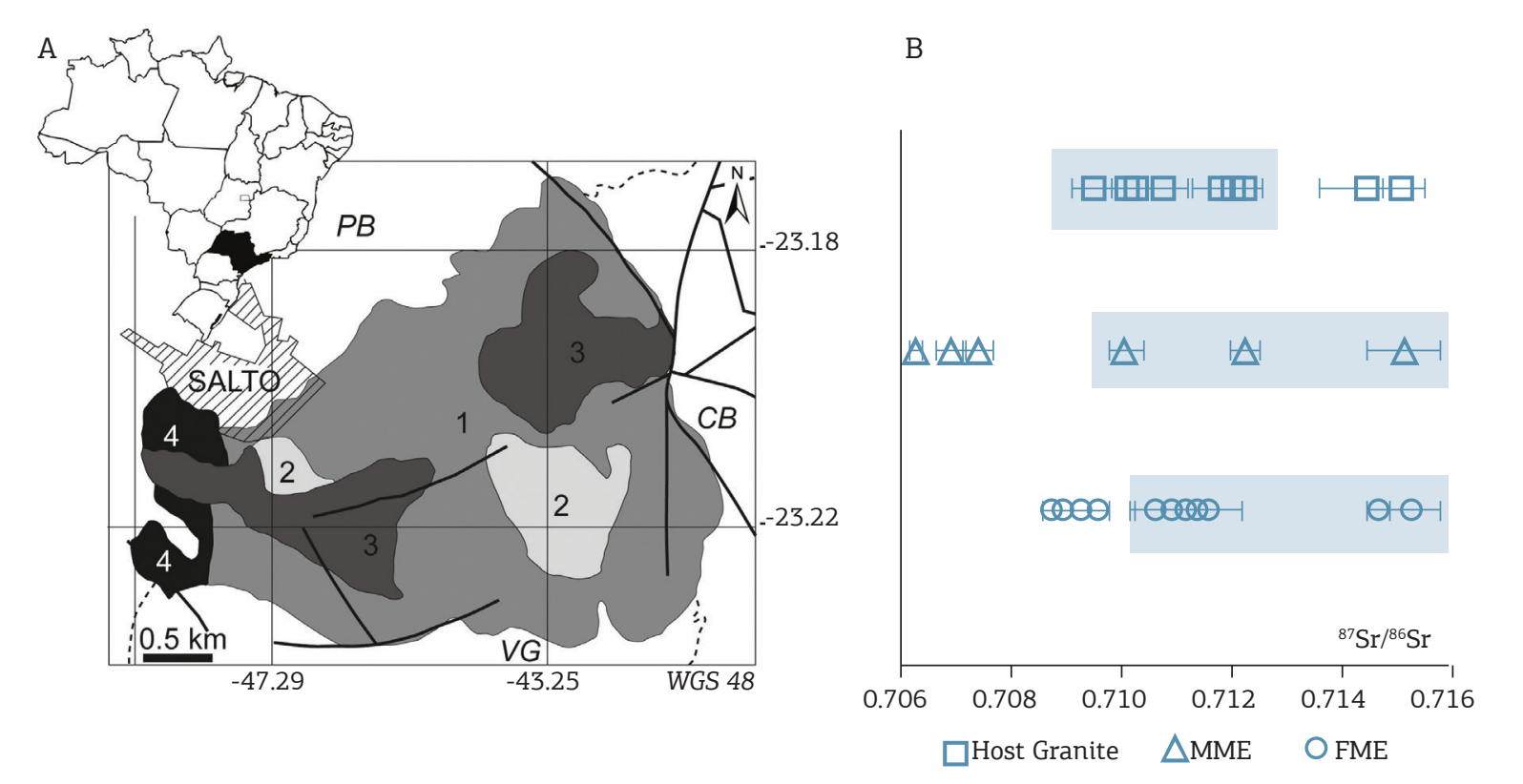

Figure 5. (A) Location of the Salto pluton, São Paulo, Southeast Brazil and its faciologic associations. 1 - rapakivi granite; 2 - red granites; 3 - porphyry granite; 4 - hololeucocratic granite. Dashed lines mark the boundaries with sediments of the Paraná Basin (PB) and the Varginha-Guaxupé Complex (VG). Thick black lines are geological faults. The dashed area corresponds to the urban limits of the city of Salto. (B) Variation of Sr isotopes of plagioclase crystals from microgranular enclaves and rapakivi granites from Salto pluton. Shaded area delimitates analyses performed in crystal cores. Error bars are $2 \sigma$ standard errors. 
(AN 35) from the central extra-Andean Patagonia (Sierra de los Chacays), Argentina (Fig. 6A). The sample belongs to the Oligocene-Miocene Somún Curá Magmatic Province (Kay et al. 2004, Remesal et al. 2011), which is composed mainly by olivine flood basalts and basaltic to trachytic bimodal eruptive complexes (Franchi et al. 2001, Remesal et al. 2001).

Plagioclase phenocrysts range from 3 to $5 \mathrm{~mm}$ at their largest dimension, are subhedral, fresh and develop polysynthetic twining (Fig. 6B.1). Both crystals show patchy zoned and resorbed areas (RA, highlighted in grey) at their cores, followed by non-resorbed (NA) or overgrown areas (OA) that locally truncate polysynthetic twinning. The largest crystal shows an external resorbed rim, followed by a boxy overgrowth (OR).

Apatite crystals are about $\sim 100 \mu \mathrm{m}$ at their basal section. They are euhedral, of short prismatic habit, and filled with dark brown rod-like inclusions parallel to the c-axis (Fig. 6B.2-3). These inclusions are evenly distributed and produce a dusky appearance. The analyzed crystals lay very close to each other, and are hosted within an anorthoclase megacryst in association to opaque minerals. The same kind of dusky apatites are observed within plagioclase and diopside phenocrysts, suggesting they were already present at relatively early-magmatic stages.

Analyses on plagioclase and apatite grains yield average ${ }^{84} \mathrm{Sr} /{ }^{86} \mathrm{Sr}$ value of $0.056034 \pm 452(2 \sigma \mathrm{SD})$ and an average
${ }^{84} \mathrm{Sr} /{ }^{88} \mathrm{Sr}$ value of $0.006689 \pm 61(2 \sigma \mathrm{SD})$, which are close to the canonical values, providing an acceptable confidence for ${ }^{87} \mathrm{Sr} /{ }^{86} \mathrm{Sr}$ determinations.

Because (1) the Aguada la Noche Sierra trachytes are young (U-Pb SHRIMP age: $24.87 \pm 0.57 / 0.21 \mathrm{Ma}$, Cordenons et al. 2014) and (2) the Rb content on both mineral phases is very low, the measured values are representative of the initial ${ }^{87} \mathrm{Sr} /{ }^{86} \mathrm{Sr}$ compositions.

A systematic behavior of $\left({ }^{87} \mathrm{Sr} /{ }^{86} \mathrm{Sr}\right){ }_{i}$ ratio is observed on plagioclase phenocrysts. Data on the unmodified NA and OA sites yield an average $\left({ }^{87} \mathrm{Sr} /{ }^{86} \mathrm{Sr}\right)_{i}$ value of $0.706264 \pm$ $587(2 \sigma$ SD), whereas individual data on RA and OR sites range from $0.705839 \pm 95(2 \sigma \mathrm{SE})$ to $0.708895 \pm 182(2 \sigma$ $\mathrm{SE})$. This large variation points to potential physicochemical instabilities in the magmatic chamber during dissolution and re-precipitation of plagioclase in an open-system scenario. Isotopic exchange with a more radiogenic reservoir might be responsible for such observations.

Data from the two apatite basal sections display $\left({ }^{87} \mathrm{Sr} /{ }^{86} \mathrm{Sr}\right)_{i}$ values of $0.706674 \pm 763(2 \sigma S E)$ and $0.708618 \pm 631(2 \sigma$ $\mathrm{SE})$ respectively. Even though such values are in the same range observed for plagioclase crystals, there is no textural evidence to support that the variations are due to a in-chamber open-system process.

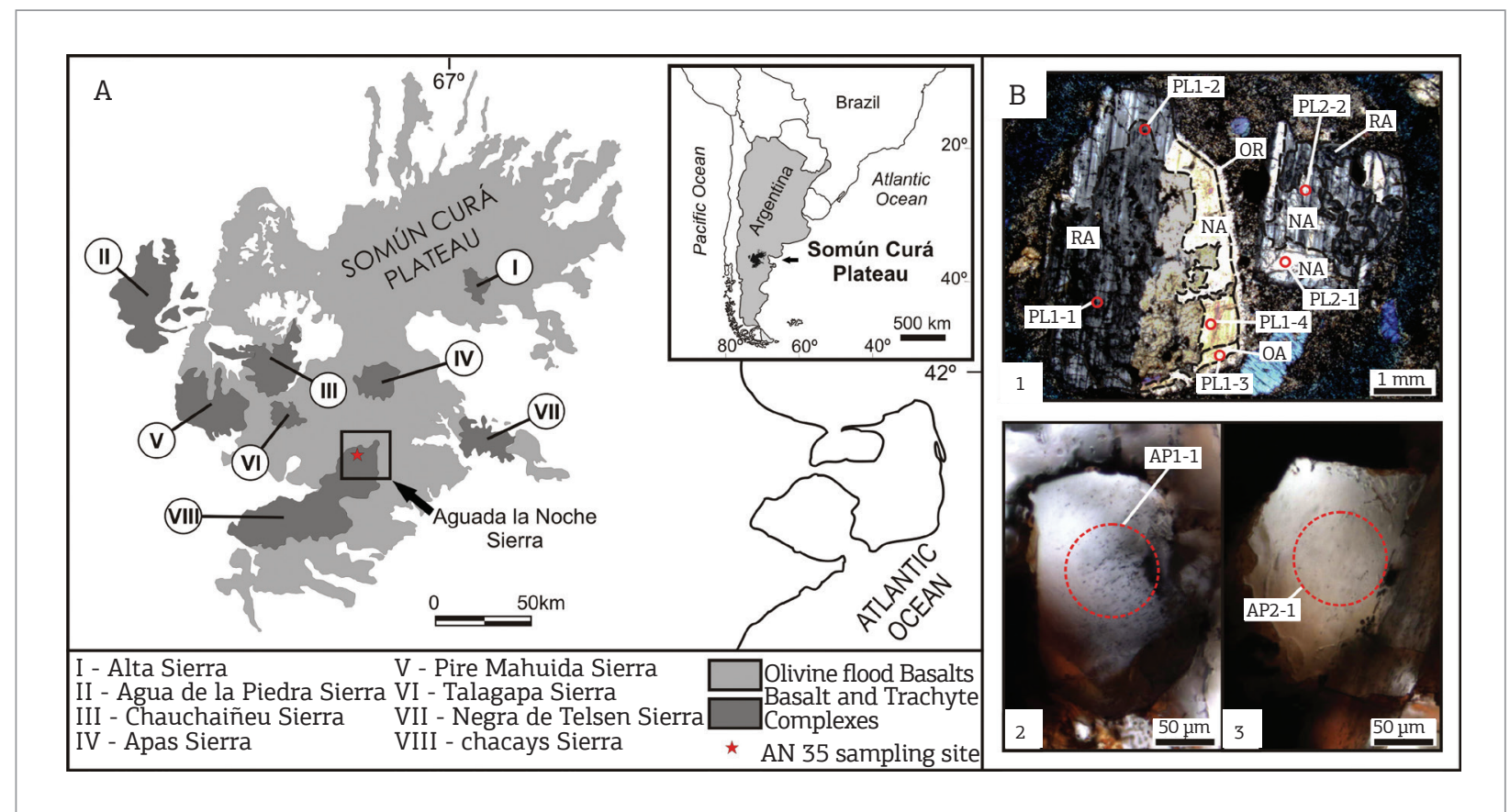

Figure 6. (A) Location of the Somún Curá mesa within South America. The main topographic accidents (Sierras) and lithologies are displayed. The AN 35 trachyte was taken from the central trachytic core of the Aguada la Noche Sierra (red star). B) Studied crystals from AN 35 trachyte sample. (1) Plagioclase phenocrysts immersed in the trachytic matrix; (2-3) Dusky apatites lodged inside an anorthoclase megacryst. Plane polarized light. Areas subjected to LA-MC-ICP-MS for isotopic determinations are encircled in red. Spots are 158 and $79 \mu$ m diameter for $\mathrm{Pl}$ and Ap respectively (to scale). See text for further details. 
The $\left({ }^{87} \mathrm{Sr} /{ }^{86} \mathrm{Sr}\right)$, ratios suggest that this trachyte could derive from a mantle source enriched in $\mathrm{Rb}$, and other mobile, large ion litophile incompatible elements. The obtained isotope ratios are compatible to those from EM I and/or EM II isotopic reservoirs. However, a larger geochemical dataset is needed in order to assess the role of alternative differentiation magmatic processes (e.g., AFC and/or magma-chamber processes).

\section{CONCLUDING REMARKS AND FUTURE DIRECTIONS}

The present contribution demonstrates the suitability of the use of in situ LA-MC-ICP-MS to the identification of spatially-controlled $\mathrm{Sr}$ isotope signatures in $\mathrm{Sr}$-rich materials (above $100-200 \mu \mathrm{g} / \mathrm{g}$ ).

Four key observations strongly support the effectiveness of the adopted protocol:

1. low deviation of stable ratios $\left({ }^{84} \mathrm{Sr} /{ }^{86} \mathrm{Sr}\right.$ and $\left.{ }^{84} \mathrm{Sr} /{ }^{88} \mathrm{Sr}\right)$ from the accepted values, both for the unknowns and reference materials;

2. low deviation of ${ }^{87} \mathrm{Sr} /{ }^{86} \mathrm{Sr}$ ratios from values independently determined via TIMS for the reference materials;

3. the lack of correlation between ${ }^{84} \mathrm{Sr} /{ }^{86} \mathrm{Sr}$ and ${ }^{87} \mathrm{Sr} /{ }^{86} \mathrm{Sr}$ ratios; and [d] external precisions with deviations lower than -100 ppm.
The first attempts to determine in situ Sr isotopes variable matrices (plagioclase, apatite and carbonates) of different geological scenarios reveal the high potential of the technique to unravel complex igneous processes such as magma mixing, source-inherited isotope heterogeneity and contamination processes. Results obtained for the Batjberg clinopyroxene point to the feasibility of application of the technique to basic igneous rocks.

\section{ACKNOWLEDGEMENTS}

We thank the reviewers for comments that improved the clarity and content of the manuscript. This work was supported by FAPESP (postdoctoral fellowship 2010/20380-4 to the leading author; research grants 2011/07074-4 to A. Alves and FAPESP 2010/20425-8 to R.G. Azzone). P. Cordenons thanks financial support from UBACyT 20020130100650BA project and also to Consejo Nacional de Investigaciones Científicas y Técnicas (CONICET). We thank Sandra Andrade and K. Sato for technical assistance. A. Simonetti is thanked for guidance during the first attempts of the method implementation. A. K. Pedersen is thanked for providing samples of Batjberg clinopyroxene.

\section{REFERENCES}

Adams C.J., Campbell H.J., Griffin W.L. 2005. Isotopic microanalysis of seawater strontium in biogenic calcite to assess subsequent rehomogenisation during metamorphism. Chemical Geology, 220:67-82.

Albarède F. \& Beard B. 2004. Analytical Methods for Non-Traditional Isotopes. Reviews in Mineralogy \& Geochemistry, 55:113-152.

Allègre C. 2005. Géologie isotopique. Belin Éditions.

Alves A., Janasi V.A., Simonetti A., Heaman L. 2009. Microgranitic Enclaves as Products of Self-mixing Events: a Study of Open-system Processes in the Mauá Granite, São Paulo, Brazil, Based on in situ Isotopic and Trace Elements in Plagioclase. Journal of Petrology, 50(12):2221-2247.

Alves A., Pereira G.S., Janasi V.A., Polo L.A., Juriaans O., Ribeiro B.V. 2015. The origin of felsic microgranular enclaves: insights from plagioclase crystal size distribution and thermodynamic models. Lithos (in press, DOI 10.1016/j.lithos.2015.09.027)

Azzone R.G. 2008. Petrogênese do maciço máfico-ultramáfico Ponte Nova (SP-MG). PhD Thesis, Universidade de São Paulo, São Paulo, 240p.

Azzone R.G., Montecinos P.M., Enrich, G.E.R., Alves A., Ruberti E., Gomes C.B. 2016. Petrographic, geochemical and isotopic evidence of crustal assimilation processes in the Ponte Nova alkaline maficultramafic massif, SE Brazil. Lithos, submitted.

Azzone R.G., Ruberti E., Enrich G.E.R., Gomes C.B. 2009. Geologia e geocronologia do maciço alcalino máfico-ultramáfico Ponte Nova (SP-MG). Geologia USP - Série Científica, 9:23-46.
Bell K. \& Simonetti A. 2010. Source of parental melts to carbonatitescritical isotopic constraints. Mineralogy and Petrology, 98:77-89.

Bizzarro M., Simonetti A., Stevenson R.K., Kurszlaukis S. 2003. In situ ${ }^{87} \mathrm{Sr} /{ }^{86} \mathrm{Sr}$ investigation of igneous apatites and carbonates using laser-ablation MC-ICP-MS. Geochimica et Cosmochimica Acta, 67(2):289-302.

Braschi L., Francalanci L., Tommasini S., Vougioukalakis G.G. 2014. Unraveling the hidden origin and migration of plagioclase phenocrysts by in situ Sr isotopes: the case of final dome activity at Nisyros volcano, Greece. Contributions to Mineralogy and Petrology, 167(3):1-25

Chen W.T., Zhou M.F., Gao J.F., Zhao T.P. 2015. Oscillatory Sr isotopic signature in plagioclase megacrysts from the Damiao anorthosite complex, North China: Implication for petrogenesis of massif-type anorthosite. Chemical Geology, 393-394:1-15.

Chen W. \& Simonetti A. 2013. In situ determination of major and trace elements in calcite and apatite, and $\mathrm{U}-\mathrm{Pb}$ ages of apatite from the Oka carbonatite complex: Insights into a complex crystallization history. Chemical Geology, 353:151-172.

Comin-Chiaramonti P., Gomes C.B., Marques L.S., Censi P., Ruberti E., Antonini P. 2005. Carbonatites from southeastern Brazil: Geochemistry, $\mathrm{O}-\mathrm{C}, \mathrm{Sr}-\mathrm{Nd}-\mathrm{Pb}$ isotopes and relationship with the magmatism from the Paraná-Angola-Namibia province. In: Comin-Chiaramonti P. \& Gomes C.B. (Eds.). Mesozoic to Cenozoic alkaline magmatism in the Brazilian Platform. São Paulo: Edusp/FAPESP, p. 657-687. 
Cordenons P.D., Schneider Santos J.O., Salani F.M. 2014. First Zircon U-Th-Pb SHRIMP Ages of the Felsic Alkaline Magmatism of the Sierra de los Chacays Volcanic Complex, Patagonia, Argentina. In: $9^{\circ}$ SSAGI, South American Symposium on Isotope Geology. São Paulo, Abstracts, p. 182.

Christensen J.N., Halliday A.N., Lee D-C, Hall C.M. 1995. In situ Sr isotopic analysis by laser ablation. Earth and Planetary Science Letters, 136:79-85.

Davidson J., Tepley III F., Palacz Z., Meffan-Main S. 2001. Magma recharge, contamination and residence times revealed by in situ laser ablation isotopic analysis of feldspar in volcanic rocks. Earth and Planetary Science Letters, 184:427-442

Farina F., Dini A., Rocchi S., Stevens. 2014. Extreme mineralscale $\mathrm{Sr}$ isotope heterogeneity in granites by disequilibrium melting of the crust. Earth and Planetary Science Letters, 399:103-115

Franchi M., Ardolino A.A., Remesal M.B. 2001. Hoja Geológica No4166-III. Cona Niyeu. Provincia de Río Negro. Escala 1: 250.000. Buenos Aires, Instituto de Geología y Recursos Minerales. Servicio Geológico y Minero Argentino.

Guo S., Ye K., Yang Y., Chen Y., Zhang L., Liu J., Mao Q., Ma Y. 2014. In situ $\mathrm{Sr}$ isotopic analyses of epidote: tracing the source of multistage fluids in ultra-high pressure eclogite (Ganghe, Dabie terrane). Contributions to Mineralogy and Petrology, 167(2).

Halliday A.N., Lee D-C, Christensen J.N., Walder A.J., Freedman P.A., Jones C. E., Hall C.M., Teagle D. 1995. Recent developments in inductively coupled plasma magnetic sector multiple collector mass spectrometry. International Journal of Mass Spectrometry and Ion Processes, 146-147:21-33.

Hodell D., Mueller P.A., Garrido J.R. 1990. Variations in the strontium isotopic composition of seawater during the Neogene. Geology, 19:24-27.

Huang Y.M., Hawkesworth C.J., van Carlsteren P., McDermott F., 1995. Geochemical characteristics and origin of the Jacupiranga carbonatites, Brazil. Chemical Geology, 119:79-99.

Jackson M.G. \& Hart S.R. 2006. Strontium isotopes in melt inclusions from Samoan basalts: Implications for heterogeneity in the Samoan plume. Earth and Planetary Science Letters, 245:260-277.

Kay S.M., Gorring M.L., Ramos V.A. 2004. Magmatic sources, setting and causes of Eocene to Recent Patagonian plateau magmatism (36오 to 52오 latitude). Revista de la Asociación Geológica Argentina, 59:556-568

Kimura J-I., Takahashi T., Chang Q. 2013. A new analytical bias correction for in situ Sr isotope analysis of plagioclase crystals using laser-ablation multiple-collector inductively coupled plasma mass spectrometry. Journal of Analytical Atomic Spectrometry, 28:945

Ludwig K.R. 2003. Isoplot 3.00. A geochronological toolkit for Microsoft Excel. Special Publication, number 4. Berkeley, Berkeley Geochronological Center, 70 p.

McCulloch M., Coppo M., Aumend J., Wolfgang M. 2005. Tracing the life history of individual barramundi using laser ablation MC-ICPMS Sr-isotopic and Sr/Ba ratios in otoliths. Marine and Freshwater Research, 56(5):637-644
McFarlane C. \& McCulloch M. 2008. Sm-Nd and Sr isotope systematics in LREE-rich accessory minerals using LA-MC-ICPMS. In: P. Sylvester (Ed.). Laser ablation ICP - MS in the Earth Sciences: Current practices and outstanding issues. Mineralogical Association of Canada, Short Course Series 40:117-133.

Montecinos P., Simonetti A., Tassinari C., Mateus A. 2014. In situ geochemical data of minerals from Jacupiranga complex carbonatites (Southern Brazil): some petrogenetic considerations. In: 30th International Conference on Ore potential of alkaline, kimberlite and carbonatite magmatism, Antalya, Turkey.

Paton C., Hergt J.M., Phillips D., Woodhead J.D., Shee S.R. 2007. New insights into the genesis of Indian kimberlites from the Dharwar Craton via in situ $\mathrm{Sr}$ isotope analysis of groundmass perovskite. Geology, 35(11):1011-1014.

Ramos F.C. Wolff J.A. Tollstrup D.L. 2004. Measuring ${ }^{87} \mathrm{Sr} /{ }^{86} \mathrm{Sr}$ variations in minerals and groundmass from basalts using LA-MCICPMS. Chemical Geology, 211:135-158.

Remesal M.B., Cerredo M.E., Salani F.M. 2011. Un Modelo Alternativo para la Génesis de la Provincia Magmática Somún Curá. In: $18^{\circ}$ Congreso Geológico Argentino. Neuquén, Actas, p. 364-365.

Schmidberger S.S., Simonetti A., Francis D. 2003. Small-scale Sr isotope investigation of clinopyroxenes from peridotite xenoliths by laser ablation MC-ICP-MS — implications for mantle metasomatism. Chemical Geology, 199:317-329.

Schobbenhaus C., Goncalves J.H., Santos J.O.S., Abram M.B., Leão Neto R., Matos G.M.M., Vidotti R.M., Ramos M.A.B., Jesus J.D.A. 2004 Carta Geológica do Brasil ao Milionésimo - Folha SF-23. Brasília, Companhia de Pesquisa de Recursos Minerais, CPRM.

Simonetti A., Buzon M.R., Creaser R.A. 2008. In situ elemental and $\mathrm{Sr}$ isotope investigation of human tooth enamel by laser ablaion(MC)-ICP-MS: successes and pitfalls. Archaeometry, 50(2):371-385.

Spiegel M.R. 1975. Theory and Problems of probability and Statistics. New York: McGraw-Hill.

Thirwall M.F. 1991. Long-term reproducibility of multicollector Sr and Nd isotope ratio analysis. Chemical Geology: Isotope Geoscience section, 94(2):85-104

Vroon P.Z, van der Wagt B., Koomneef J.M., Davies G.R. 2008 , Problems in obtaining precise and accurate $\mathrm{Sr}$ isotope analysis from geological materials using laser ablation MC-ICPMS. Analytical and Bioanalytical Chemistry, 390(2):465-476.

Waight T., Baker J., Peate D. 2002. Sr isotope ratio measurements by double-focusing MC-ICPMS: techniques, observations and pitfalls. International Journal of Mass Spectrometry, 221(3): 229-244.

Woodhead J.D., Swearer S., Hergt J., Maas R. 2005. In situ Sr-isotope analysis of carbonates by LA-MC-ICPMS: interference corrections, high spatial resolution and an example from otolith studies. Journal of Analytical Atomic Spectrometry, 20:22-27

Yang Z., Fryer B., Longerich H.P. 2011. 785 nm femtosecond laser ablation for improved precision and reduction of interferences in $\mathrm{Sr}$ isotope analyses using MC-ICP-MS. Journal of Analytical Atomic Spectrometry, 26(2):241-351.

Available at www.sbgeo.org.br 